\title{
Örgütsel Vatandaşlık Faktörlerinden Nezaket Davranışının, Çalışanların Hizmet Kalitesine Etkilerinin Analizi \\ (The Effects of Guarantee Behavior Analysis's for Organizational Citizenship Factors on The Service Quality of Employees)
}

\section{Nuran VARIŞLI iD a}

a Sosyal Güvenlik Kurumu, Ankara, Türkiye. gulmennuran@hotmail.com

\begin{tabular}{|c|c|}
\hline MAKALE BİLGİSİ & ÖZET \\
\hline Anahtar Kelimeler: & Amaç - Bu çalışmanın temel amacl, örgütsel vatandaşlık faktörlerinden nezaket davranışının, \\
\hline Örgütsel Vatandaşlık & çalışanların hizmet kalitesine etkilerini; demografik değişkenler ile vatandaşlık faktörlerinden \\
\hline Nezaket & 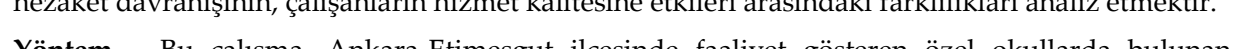 \\
\hline Hizmet Kalitesi & $\begin{array}{l}\text { Yöntem - Bu çalışma, Ankara-Etimesgut ilçesinde faaliyet gösteren özel okullarda bulunan } \\
\text { çalışanların sergilemiş oldukları nezaket davranışının; çalışanların hizmet kalitesine ne gibi etkileri }\end{array}$ \\
\hline \multirow[t]{3}{*}{ Verimlilik } & olduğunu araştırmak için yapılmıştır. Araştırmanın evrenini, özel okullarda çalışmakta olan 1900 \\
\hline & $\begin{array}{l}\text { kişi oluşturmaktadır. Araştırma anketlerinden elde edilen verilere; güvenilirlik analizi, faktör } \\
\text { analizi, veri analizi, korelasyon analizi ve regresyon analizleri uygulanmıştır. }\end{array}$ \\
\hline & Bulgular - Bu çalışma için yapılan regresyon analizi için uygulanan denklem sonucunda; okullarda \\
\hline Gönderilme Tarihi 9 Mayıs & gösterilen nezaketin, hizmet kalitesi üzerinde pozitif yönde bir etkisi olduğu tespit edilmiştir. \\
\hline 2020 & Nezaket puanının bir birim arttığı durumda, hizmet kalitesi puanının 0,806 birim artacağı tespit \\
\hline Revizyon Tarihi 1 Eylül 2020 & \\
\hline Kabul Tarihi 20 Eylül 2020 & $\begin{array}{l}\text { Tartışma - Yöneticilerin nezaket kuralları çerçevesinde davranmasının, çalışanların hizmet kalitesi } \\
\text { üzerinde pek çok olumlu etkisi bulunmaktadır. İşletmelerin yoğun bir rekabet ortamı içindeki en } \\
\text { büyük güçleri, insan gücü olmaktadır. Örgütsel Vatandaşlık Davranışının (ÖVD) çalışanlar } \\
\text { tarafından benimsenmesi ve sergilenmesinin önemli olmasının nedeni; çalışanlar arasında } \\
\text { koordinasyonu sağlaması, iletişimi güçlendirmesi ve bu sayede çalışanların motivasyonunun }\end{array}$ \\
\hline Makale Kategorisi: & $\begin{array}{l}\text { arttırmasıdır. Dolayısıyla bu tür bilimsel çalışmalar sayesinde: yöneticiler nezaket kuralları } \\
\text { çerçevesinde davranmanın avantajlarını daha çok fark edebilir; çalışanlar, ekip ve gruplar }\end{array}$ \\
\hline & $\begin{array}{l}\text { arasındaki koordinasyonun sağlanmasında birbirlerine daha fazla yardımcı olabilir; ÖVD çalışanın } \\
\text { ve örgütün verimliliğini artırılabilir; bulunulan ortamdaki dönüşüm ve değişimlere daha kolay } \\
\text { uyum sağlamada yardımcı olabilir; yetenekli çalışanların sürekliliği sağlanabilir; işe yeni } \\
\text { başlayanları örgüte cezbetme alı̧̧anlığını kazandırılabilir ve sunulan hizmetlerin kalitesinde } \\
\text { süreklilik sağlanabilir. }\end{array}$ \\
\hline
\end{tabular}

\begin{tabular}{l}
\hline ARTICLE INFO \\
\hline Keywords: \\
Organizational Citizenship \\
Courtesy \\
Service Quality \\
Productivity
\end{tabular}

\section{ABSTRACT}

Purpose - The main purpose of this study is to examine the effects of courtesy behavior, one of the factors of organizational citizenship, on the service quality of employees; To analyze the differences between demographic variables and the effects of civic factors, courtesy behavior, on the service quality of employees.

Design/methodology/approach - This study is based on the organizational citizenship behaviors of the employees in private schools operating in Ankara-Etimesgut district; It was conducted to investigate the effects of employees on service quality. The universe of the research consists of 1900

Received 9 May 2020 people working in private schools. Data obtained from research questionnaires; Reliability analysis, factor analysis, data analysis, correlation analysis and regression analysis were applied.

Revised 1 September 2020

Accepted 20 September 2020

Findings - As a result of the equation applied for the regression analysis for this study; It has been determined that courtesy shown in schools has a positive effect on service quality. It has been determined that when the courtesy score increases by one unit, the service quality score will increase by 0.806 units.

Article Classification:

Research Article
Discussion - Managers' behavior within the framework of courtesy rules has many positive effects on the service quality of the employees. The greatest strength of enterprises in an intense competitive environment is human power. The reason why it is important that Organizational Citizenship Behavior (ÖVD) is adopted and displayed by employees; It provides coordination among

\section{Önerilen Atıf/Suggested Citation}

Varışlı, N. (2020). Örgütsel Vatandaşlık Faktörlerinden Nezaket Davranışının, Çalışanların Hizmet Kalitesine Etkilerinin Analizi, İşletme Araştırmaları Dergisi, 12 (3), 3089-3109. 
employees, strengthens communication and thus increases the motivation of the employees. Therefore, thanks to such scientific studies: managers can become more aware of the advantages of acting within the rules of courtesy; employees can further assist each other in ensuring coordination between teams and groups; ÖVD can increase the productivity of the employee and the organization; It can help you adapt more easily to the transformations and changes in the environment; continuity of talented employees can be ensured; The habit of attracting new recruits to the organization can be gained and the quality of the services provided can be sustained.

\section{GİRIŞ}

Bu çalışmanın amacı, örgütsel vatandaşlık faktörlerinden nezaket davranışının, çalışanların hizmet kalitesine etkilerini ortaya koymaktır. Küresel ve yüksek rekabet ortamı içinde bulunan işletmeler, rakip işletmeler üzerinde rekabet üstünlüğü sağlamayı amaçlamakta ve bu yolla da ayakta kalmak için mücadele verirler. Verilen mücadele içinde başarı elde edebilmenin en önemli koşullarından biri; çalışanların yeteneklerinden ve güçlerinden yararlanarak hizmet kalitesini arttırmaktır. Bu çerçevede nezaket davranışı, hizmet kalitesini artırmak amacıyla çalışanların işletmeye yapmış oldukları katkıların biçimsel anlamdaki rollerinin de ötesine geçmiş olduğu önemli davranış şekillerinden biridir.

Çalışanların gönüllü şekilde sergilemiş olduğu ÖVD, genel olarak işletmeler ve çalışanlar üzerinde olumlu etkiler yaratmaktadır. Çalışanların sergilemiş olduğu ÖVD, hizmetleri kalitesini arttırmakla birlikte çalışanların işletmeye daha da bağlanmalarını sağlamaktadır (Polatcı ve Cindiloğlu, 2013: 300). ÖVD, çalışanların bir bütün şeklinde işletmenin işleyişini geliştirmekte olan tüm davranışları temsil etmektedir. ÖVD'nin pek çoğu tek başına işletmenin performansını geliştirici niteliğe sahip olmayabilir (Yasım ve Işık, $2017: 377)$

ÖVD; kişilerin çalışma ortamlarında kendileri için belirlenmiş olan resmi görev, nezaket kurallarına uygun davranışlar, sorumluluk ve standartların da ötesinde gönüllü şekilde çaba sarf etmesi ve ekstra bir rol davranışı ortaya koyması şeklinde tanımlanabilir (Göksoy vd., 2014: 103). Nezaket kurallarına uygun davranış; örgütün arzuladığı, istediği zamanda örgütsel başarıya ve etkililiğe katkı sağladığı, gönüllülük esasına dayanan bir davranıştır. Çalışanların, bulundukları örgütlerde kendilerinden istenilen sorumluluk ve görevlerin haricinde çalışma isteği ve sorumluluk bilinci, etkili ve başarılı örgütlerin temel prensiplerinden biridir. Yüksek bir performansla çalışma sergileyen örgütlerin, verimliliğin artırılması ve beklenenin ötesinde daha fazla çalışarak ekstra gayret sarf etmeleri, çalışanların arasında "biz büyük bir aileyiz" kültürünü oluşturmaktadır (Çavuş ve Develi, 2015: 231). Örgüt; değer, misyon, vizyon ve hedeflerine yoğunlaşmış bir örgütsel davranış ortaya koymaktadır. Bu nedenle, örgütler açısından en önemli konularının başında ÖVD gelmektedir (Avc1, 2015: 12).

Nezaket kurallarına uygun davranışlar; örgütün gelişimine katkı sağlayan, örgütü istenmeyen ve yıkıcı davranışlardan koruyan, örgütün çıkarlarını kendi çıkarlarından üstün tutan, çalışma arkadaşlarına her türlü yardımı veren ve onların gelişmelerine katkı sağlayan, sadakat ve özverili anlayışı ifade etmektedir. Aynı zamanda nezaket davranışları, örgütün çağdaş yeniliklere ayak uydurabilmesi, öğrenme yeteneğine sahip olması, rekabet üstünlüğü elde etmesi, verimliliğini ve başarısını artırmasında temel belirleyici konumunda yer almaktadır (Williams ve Anderson, 1991: 602).

Nezaket davranışları, örgüt için fayda sağlayan ve herhangi bir emre bağlı kalmayan ortak kültür anlayışı olarak adlandırılmaktadır (Çavuş ve Develi, 2015: 233). Nezaket kurallarına uygun davranışlar; işletmelerin sağlıklı işleyişlerini engelleyen istenmeyen ve yıkıcı davranışlardan korumak, çalışanların beceri ve yeteneklerini geliştirmek, etkili bir koordinasyon sağlayarak çalışanların performanslarını ve verimliliğini arttırmayı amaçlamaktadır. Çalışanların performansları onların işletme performanslarına, kurumların sürekliliğine ve hizmet kalitesine yansımaktadır (Karaman ve Aylan, 2012: 39-40).

\section{KAVRAMSAL ÇERÇEVE}

\section{1. Örgütsel Vatandaşlık Davranışı Kavramı}

Örgütsel vatandaşlık kavramı, örgütlere fayda sağlayan ve emirlere bağlı kalmayan davranışlar şeklinde tanımlanabilir. ÖVD, örgütlerde yardımlaşmayı ve centilmenliği içeren rollerden oluşmaktadır. Vatandaşlık, kişiler ile devlet arasında anayasa ve yasalarla tanımlanmış olan hak ve ödevlere dayanan bağlar olarak tanımlanmaktadır (Polatçı ve Cindiloğlu, 2013: 301). ÖVD'yi isteğe bağlı olarak davranışların içinde, formel 
ödül verme sistemi içerisinde doğrudan ve açık olarak bulunmayan, işletmelerin fonksiyonunu arttırmayla ilişkili kişisel davranışlar bütüne denilmektedir (Sezgin, 2005: 324).

ÖVD, çalışanların işletmeye olan sorumlulukları ve görevleri dışında sergilemiş oldukları gönüllü çabalar şeklinde tanımlanabilir. Örneğin çalışanlar tarafından sergilenen kişiler arası nezakete dayalı davranışlar; çalışanların tamamıyla kendi istekleri doğrultusunda işletme amaçlarına katkı sağlayabilmek için gerçekleştirmiş olduğu davranışlardır (Nergiz, 2016: 217).

ÖVD’nin amaçlarını gerçekleştirilebilmesi açısından örgütsek sadakat büyük önem taşımaktadır. Örgütsel sadakat, gönüllü olarak örgütte gerekenden fazla görev ve sorumlulukların alınmasıdır. Örgütlerin başka bireylere yüceltilip, görevlerin yerine getirilmesinde mesleki uygunluğa dikkat etmeleri, diş tehditlere karşı savunulması ve korunması, örgütün iyi tanıtımının yapılıp, olumsuz şartlarda dahi örgütle bağlı kalınabilme davranışlarını kapsamaktadır (Göksoy vd., 2014: 104). ÖVD, örgütün işleyişini önemli derecede etkilemektedir. Örgütlerin yapılarının değişmesinde, gelişmesinde ve biçimlendirilmesinde ÖVD'nin rolü büyüktür. Çalışanların örgüt içerisinde bütünleşebilmesi, ilişkileri ve insanlar arasındaki davranış boyutları örgütleri etkilemektedir. ÖVD'nin, örgütün işleyişine ve başarısına olan etkisinin temelinin bu ilişkilere dayandığı görülmektedir (Demirtaş, 2010: 1069).

Kurumlarda başarının sağlanması, insan kaynaklarının nitelikli olmasıyla yakından ilgilidir. Kurumların başarılı olabilmesi için, elektronik sistemler, veri tabanları, yeni teknolojiler ve üstün yönetim sistemleri gerekmektedir. Toplumların sosyal, ekonomik ve politik gelişmelerinde, örgütlerin etkinliklerinde ve verimliliklerinde insani etkenlerin önemi oldukça büyüktür. ÖVD'nin artış göstermesinin üç temel sebebinin olduğu belirtilmektedir (Kaya, 2013: 265);

1. Birinci sebep, davranış sonucu oluşan performansın, çalışan performansının değerlendirilmesinde terfi ve ücret uygulamasının da dikkate alınmasıdır. ÖVD'nin gösterilmesinde yöneticiler, çalışanlara karşı herhangi bir güç veya yaptırım kullanmamaktadır. Çalışanlar gösterdikleri nezaket davranışlarının sonunda herhangi bir ödül beklentisinde değillerdir. Yöneticiler dolaylı veya dolaysız olarak insani kaynakları uygulamasında, örgütsel vatandaşlık davranışlarını dikkate alarak ödüllendirmektedirler (Göksoy, vd., 2014: 105).

2. İkinci sebebi, ÖVD'nin örgütün başarısına ve etkinliğine olan katkılarının olmasıdır. ÖVD, örgütlerin performansını ve örgütsel etkinliğini arttırmaktadır. ÖVD'nin bireyin kendisini motive ederek ait olma, başarabilme ve yetkinlik duygularını oluşturduğunu açıklamaktadır.

3. Üçüncü sebep ise, ÖVD'nin örgütsel bağll1ık, işten ayrılmalar, vatandaşlığa ters düşen davranışlar, iş tatminleri ve örgütsel adalet gibi yakın ilişkilerinin olmasıdır. ÖVD'nin önemi, çalışanların ve örgütlerin, örgüt içerisinde davranışlarının ÖVD olarak nitelendirilmesidir (İpek, 2012: 431).

\section{3. Örgütsel Vatandaşlık Davranışının Sebepleri}

ÖVD; beklentisiz, karşılık beklemeyen, gönüllü ve beklenenlerin ötesinde olan tüm davranışlardır (Paşamehmetoğlu ve Poyraz, 2013: 76). Bireylerin herhangi bir beklentisi yoksa; örgütler de aynı davranışları sergilemektedirler. Örgütlerde belirli sayıda çalışan, vatandaşlık davranışları göstermektedir. Aynı şekilde örgütlerde de belirli sayılardaki çalışanlar, üstün düzeyde vatandaşlık davranışları göstermektedirler. Bir örgütteki bireyin vatandaşlık davranışı sergilemesinin temel sebepleri şu şekilde sıralanabilir (Özdevecioğlu, 2009: 52);

1. Sektörde iş birliğinin gerekliliğ̈i,

2. Tedarik halkalarının bir parçası olabilmek,

3. Ortak yatırımlar veya ortak projelerde çalışıyor olmak,

4. Başarılı olabilmede beraberliğin gerekliliğ̈i,

5. Aynı işletmelerde bayii veya satıcısı olmak,

6. Rekabetlere karşı birlikte hareket etmek,

7. Konsorsiyum oluşturabilmek,

8. Örgütlerin bir bütün halinde olması ve bütünsellik taşıması,

9. Farklı işletmelerin dış kaynağı olabilmek. 


\section{4. Örgütsel Vatandaşlık Davranışının Özellikleri}

ÖVD, gönüllülük esasında etkisini artırmaktadır ve kurumsallık açısından örgütlere önemli faydalar sağlayabilmektedir. (Özdevecioğlu, 2009: 60);

ÖVD, iş tanımının içerisinde işçilerin doğrudan ya da dolaylıda olsa yer alamayan, bu resmi zorunluluk veya işin tanımının ötesinde bir davranıştır. Bu şekilde davranışta bulunan kişilerin isteğine bağlıdır. Bu davranışları göstermelerinde herhangi bir ödül verilmez, gösterilmediği durumlarda ise; herhangi bir ceza uygulanmaz ve davranış tamamen kişinin isteğine bağlıdır. Çalışanların, örgütsel vatandaşlık davranışlarını göstermek için eğitim almaları gerekmemekte, bunlar tamamen kişilerin içinden gelerek yapmış oldukları davranışlardır. ÖVD bir bütün olarak örgütlerin işlevselliklerini de artırmaktadır (Organ, 1988: 43).

\section{6. Örgütsel Vatandaşlık Davranışının Boyutları}

ÖVD, çalışanların işletmelere veya işletme üyelerine yönelik gerekli zorunlulukları ve görevleri haricinde göstermiş oldukları davranışlar bütünü olarak tanımlanmaktadır (Paşamehmetoğlu ve Poyraz, 2013: 77).

Çalışanlar, ÖVD ile örgütsel özdeşleşme seviyeleri konularında etkili olmaktadırlar. . Örgütler, sosyal hayatlarında kazandıkları saygınlığın, üyesi oldukları örgütün yüksek itibarlı olması ile orantılıdır. Örgütlerin özel programları, tarihi geçmişleri ve sosyalleşme faaliyetleri (piknikler, şirket yemekleri vb.) gibi uygulamaları, fark oluşturmalıdır (İpek, 2012: 431).

Örgüt içerisindeki çalışma gruplarında ayrıcalık olması diğer gruplarda dikkat çekmektedir. Birlikte çalışan farklı grupların işçileri, kendi gruplarına ait olan bazı özellikleri ön plana çıkartır. Bu da "ben" kavramını ortadan kaldırarak "biz" kavramını getirmektedir. Örgütlerdeki kurumsal imajın yüksek olması, çevredeki diğer insanlarca yansıma şeklinde geri dönmektedir. Eğer bu yansıma şekli olumlu ise, işçiler örgütler ile daha güçlü olarak özdeşleşecektir (Gürbüz, 2008: 70).

Görev performansı ya da görevsel tanımlamalarda bulunmayan birtakım davranış şekilleri olarak da ifade edilmektedir. Çalışanlar davranış biçimlerini yerine getirmediği durumlarda, herhangi bir ceza almamaktadırlar (Yeşiltaş vd., 2011: 174). ÖVD'nin boyutlarından özgecilik, vicdanlılık, centilmenlik, nezaket ve sivil erdem şeklinde izah edilebilir:

Özgecilik kavramı, işletmedeki çalışanların gönüllü olarak diğer arkadaşlarına yardım etme yoluyla onların performanslarını ve etkinliklerini artırmaya yönelik davranışlarda bulunmaları olarak ifade edilmektedir (Altıntaş, 2006: 84). İşletmelerde kıdemli ya da deneyimli veya uzman çalışanların, işe yeni giren arkadaşlarına yardımda bulunması özgecilik olarak kabul edilmektedir. İşletmelerde kişilere yönelik yardımcı olma davranışlarını ifade eden özgecilik, kişisel düzeyde bir davranış olmasına karşın, bu durumdan işletmelerin yarar sağladığı görülmektedir (Sezgin, 2005: 323).

Vicdanlılık kavramı, işletme çalışanlarının kendilerinden beklenilen davranışların haricinde davranışlar ortaya koymalarında gönüllü olmaları gerektiğini ifade etmektedir. Örgütsel vatandaşlık davranışlarından biri olan vicdanlılık, çalışanların işlerini tamamlamadan işyerini terk edemedikleri bir davranıştır (Karaman ve Aylan, 2012: 39-40).

Centilmenlik kavramı, kaynaklarda fazla ilgi görmeyen bir örgütsel davranış şekli olarak bilinmektedir. Organ centilmenliği ise, işin neden olduğu kaçınılmaz rahatsızlıklara ve zorlamalara, bireyin anlayışla yaklaşması şeklinde tanımlanmaktadır. Kaçınılmaz zorlukların hemen her işletmede yaşandığı görülmektedir. Centilmen bir birey, tüm bu olumsuzlukları memnuniyetle karşılar ve küçük sorunları fazla büyütmez (Kaya, 2013: 281282).

Centilmenlik ve gönüllülük, örgüte ve lidere bir bütün olarak bağllığı içermektedir. İşçilerin rahatsızlıklara ve ağır yüklere karşı katlanmaya istekli olmaları, işlerin yolunda gitmediği durumlarda bile olumlu tavır sergilemeleri ve astlarının ilgisini örgütlerin menfaati yönünde kullanmalarını sağlaması şeklinde tanımlanabilir (Podsakoff vd., 2000: 517).

Nezaket kavramı, işletmelerde işin sorumlulukları nedeniyle devamlı olarak iletişim halinde olmalarını sağlayan, aynı zamanda birbirinin işlerinden ve kararlarından etkilenen işletme çalışanlarının gösterecekleri olumlu davranışlardır. Yüksek derecede iletişim becerisine sahip olabilme, işletmeler için başarıya ve eşgüdüme götüren bir yol olmaktadır (Karaman, 2013: 265). 
Kurumda çalışanların işleri gereği her zaman iletişim içerisinde olmaları, birbirlerinin kararlarından ve işlerinden etkilenen bireylerin, birbirlerini önceden uyarmaları, bilgileri aktarmaları, birbirlerine gereken hatırlatmaları yapmaları ve danışmaları nezaket davranışlarına örnek olarak verilebilir. Nezaket ile özverili olma terimleri "yardımseverlik" olarak tanımlandıkları için ikisini de birbirinden ayırt etmek oldukça güçtür. İki terim arasındaki görülen fark, yardım etme anında gerçekleşen zamana göredir. Özverili olma; kişilerin birbirlerine olumsuz bir durum ortaya çıtıktan sonra, o sorunu ortadan kaldırmak amacıyla yardım etmeleri şeklindedir. Nezaket teriminde ise, olumsuz bir durumun ortaya çıkmasını engellemek ya da o sorunun derecesini azaltmak maksadı ile önceden önlem almayı gerektiren davranışlardır (Podsakoff vd., 2000: 521).

\subsubsection{Sivil Erdem}

Sivil erdem, işletmeye makro düzeyde olan bağlılı̆̆1 ve ilgiyi, örgütsel hayata aktif ve gönüllü olarak katılım sağlamaya denilmektedir (Çetin, 2004: 21). Bu ilginin örgüt yönetimine aktif olarak katılmakla, örgüt çevresindeki tehditleri ve fırsatları etkili bir biçimde gözlemleme ile gösterilmektedir. Basit olarak makro düzeyde bir maliyete sahip olsalar dahi, yönetime girme konusundaki isteklilik, işletmelerin karşılaştıkları fırsatları ve tehditleri gözlemlemek, işletme için en iyilerini yapmaya çalışmak gibi davranışlar bu boyut içerisinde yer almaktadır (Kaya, 2013: 283).

\section{7. ÖRGÜTSEL VATANDAŞLIK, HIZMET KALİTESİ VE ÇALIŞAN MOTVASYONU İLİŞKİSİ}

Bu kısımda, örgütsel vatandaşlık, hizmet kalitesi ve çalışan motvasyonu ilişkisine yer verilecektir.

\subsubsection{Hizmet Kalitesi Kavramı}

Hizmet kalitesi, müşteriler üstün hizmetlerin sunulması veya beklentilerinin karşılanması olarak tanımlanabilir (Demireli ve Bayraktar, 2014: 920). Hizmet sektörü açısında kalite; algılama, kontrol edebilme, sürekliliği sağlama ve uygulanabilirlik bakımından karmaşık, güç ve belirsiz bir kavramdır. Hizmet sektörü açısından hizmetin kalitesi, hizmet gören kişiden kişiye değişiklik göstermektedir. Meydana gelen bu değişiklik de sunulan hizmetin mallara oranla standardizasyonunun hiç yok denilebilecek kadar minimum düzeyde olduğunu ortaya koymaktadır (Kılıç ve Eren, 2009: 92).

Hizmet veren işletmeler için kalite anlayışının müşteriler tarafından algılanması oldukça önemlidir. Hizmet kalitesini belirleyen temel faktörler şu şekilde sıralanmaktadır (Demireli ve Bayraktar, 2014: 920).

1. Örgütsel yapı,

2. Hizmet içi eğitim,

3. Örgütsel yapıya katılımın sağlanması,

4. Ücretler konusunda adaletli dağıtım,

5. İş güvenliğinin oluşu,

6. Ortama sunulan rahatlığın uygun oluşu,

7. Gelişen teknoloji,

8. Yetki ile sorumluluklar ilkesi,

9. İşle alakalı tüm bilgilendirmelerin yapılarak bütün yönleriyle açıklanması,

10. Sosyal imkânların sunulması,

11. Yöneticiler ile çalışanlar ve çalışanlar ile çalışanlar arasındaki ilişki.

Hedeflere ulaşmada gösterilen hizmet kalitesinin, başarıyı ölçmede bir araç olduğu ifade edilmektedir. (Uysal, 2015: 33). Hizmet kalitesi açısından iyi performans sergilemeyen çalışanlar, terfi olarak görevlerinden istifade etme haklarını kaybetmektedirler. Böylece çalışanlar belirli amaçları gerçekleştirmek için performanslarını artırmada kendi arzu ve istekleriyle çaba gösterebilir (Bingöl, 2016: 9).

\subsection{3. Çalışan Motivasyonun Artırılmasının Faydaları}

İş hayatında rekabet her zaman yoğun olarak bulunmaktadır. Bu rekabette başarı sağlamanın, lider olabilmenin ve en önemlisi de çalışanların motivasyonunu arttırarak çalışanların başarısını gerçekleşecek değişimlere ayak uydurmak ve güçlü bir yapıya sahip olmaktan geçmektedir. Bireysel etkinlik, verimliliği artırmada çalışanların motivasyonunun sağlanması noktasında oldukça önemlidir (Bayram, 2006: 47).

Çalışanların motivasyonunun sağlanması ve grup çalışmalarının teşvik edilmesi; işletme birimleri veya çalışanlar arasında bütünleşmeyi sağlayıp, bireyler arasındaki bilgi paylaşımını ve bilgi alışverişini artırır 
(Hunton vd., 2003: 166); İşletmeler, çoğunlukla müşterisinin isteğini karşılayıp karşılayamadıklarını tespit edebilmek, yaptıkları faaliyetlerde bildiklerinin doğru olup olmadığını onaylayabilmek ve neyi bildiklerini açığa çıkarmak için performans ölçümleri yapmaktadırlar. Çalışan motivasyonunu artırılmasının, işletmeye sağladığı pek çok fayda vardır. Bunlar şekilde sıralanabilir (Parker, 2000: 63);

Rekabet, işletmelerin diğer işletmelere karşı üstünlük elde edebilmeleri açısından önemlidir. İşletmelerin rekabet üstünlüğü elde etmek istemelerinin nedenlerinden biri ise, daha iyi bir ürün veya değer yaratmak istemeleridir. İşletmeler, rekabette üstünlügü yakalayabilmek için kendisinden beklenilenden daha fazla performans gösteren çalışanlara gereksinim duyarlar. Bu davranışlar, işletmelerin hayatta kalabilmeleri için oldukça önemlidir. Çalışanlara gönüllü davranış diye tanımlanan kavram kaynaklarda, ÖVD adıyla anılmaktadır (Van Dyne vd., 1994: 768).

ÖVD sergileyen işçiler sayesinde, gönüllü davranışlar gösteren işçilerin keşfedilip, işletme süreci boyunca verimlilik ve süreklilik gibi konularda başarı elde edilmesi sağlanmaktadır. Örgütsel davranış biçiminin etkili olabilmesinde işverenlere, yöneticilere ve insan kaynaklarına büyük görevler düşmektedir. Farklı yapıdaki insanların yapmış oldukları uygulama alanları ile nezaket davranışlarının işletmelerde oluşturulması ve artırılması mümkün olabilmektedir. Farklı yapıdaki insan kaynakları, belli bir süre zarfında işçilerin örgütsel vatandaşlık davranışlarını ortaya koymalarını amaçlamaktadırlar. Performans yönetim sistemleri, seçme yerleştirme süreçleri, tatmin edici veya finansal gibi teşvik programlarını yaşama geçirmektedirler (Karalar, 2008: 13).

Başarı elde etmek isteyen işletmelerin, rekabet üstünlüğü sağlayabilecek akıllı davranışlar sergileyebilmesi gerekmektedir (Edward, 2000: 24). Rekabet üstünlüğü sağlamayı amaçlayan işletmelerdeki çalışanların kararlara aktif şekilde katılım sağlamaları, kaynakların verimli bir şekilde kullanılmasını sağlamaktadır. Dolayısıyla, rekabet üstünlügüunün sağlanabilmesi için işletmelerin, ÖVD sergileyen çalışanların motivasyonlarını arttırıcı girişimlerde bulunması işletmelere fayda sağlayacaktır.

Rekabet üstünlüğünün sürdürülebilmesi ve elde edilebilmesi, strateji kavramı olarak ifade edilmektedir. Değişimlerin hızlı bir şekilde gerçekleşmesi, işletmelerin belirsiz ortamlarda faaliyet göstermelerine neden olmaktadır. İşletmeler böylece küreselleşmeyle rekabette üstünlük sağlamaya ve stratejilerini geliştirmeye çalışmalıdırlar (Kara vd., , 2018: 150).

Finansal performans yani işlemlerin elde edilmesini sağlayabilecek karlılık açısından performans ölçümleri zor olan hizmet sektörlerinde finansal performans daha belirgin olarak hissedilmektedir. İşletmeler uzun bir dönem finansal performans elde etmek istiyorlarsa; yapılarını, müşterinin arzu ettiği hizmetleri ve ürünleri, üretecek şekilde çalışanları istihdam etmeleri gerekmektedir (Kaplan ve Norton, 1999: 81-82).

Esneklik kavramı, kısa bir zaman diliminde az bir çaba ve maliyetle veya çalışan performansıyla değişikliklere uyum sağlayabilme yeteneği şeklinde tanımlanabilir (Arslantaş, 2008: 101). Söz konusu yetenek, yoğun bir rekabet ortamı içinde bulunan küresel ekonomik yapıda örgütlerin rekabet üstünlüklerini koruyabilmeleri bakımından büyük bir önem taşımaktadır. Hızlı bir şekilde değişmekte olan küresel piyasalarda esneklik; istihdama ve üretime yönelik olan bütün sınırlayıcı engellerin ve yasal düzenlemelerin de gevşetilmesini ortaya koyar (Pollert, 1988: 282). İşletmelerde herhangi bir olumsuzluk karşısında sistemlerde bazı düzeltmelere gidilmeyip, aksine işletmelerin yeniliklere uygun olarak tekrardan yapılanmaları istenmektedir (Demir ve Taşkın, 2008: 1704).

Dış kaynak kullanımı, işletmelerin hizmet kalitesini arıtmasında önemli rol oynayan maddelerden bazıları şu şekilde sıralanabilir (Hasan, 2005: 158); maddeler halinde yazılacak olunursa;

1. Dış kaynak kullanımı, organizasyonların diğer organizasyonlardan girdi olarak ürün veya hizmet sağlamasıdır.

2. Dış kaynak kullanımı, organizasyon içerisinde elde edilen hizmetlerin ve malların, dışarıdan satın alınmasının sağlanmasıdır.

3. Dış kaynak kullanımı, ürünün imalatında kullanılacak gerekli araç ve gereçlerin veya KDV oluşturucu çalışmaların, dışarıdan kaynak aracılığıyla sağlanmasıdır. 


\subsection{5. Örgütsel Vatandaşlık Davranışının Hizmet Kalitesine Etkisi}

Çalışanların hizmet kalitesi birçok boyutlara sahip olduğundan; nitel ve nicel performanslarla aynı anda kullanılarak ölçümleri sağlanmaktadır. İşletmelerin amaçlarını yerine getirme noktasında tüm çalışan çabalarının toplamı, hizmet kalitesi olarak tanımlanabilir (Baytok ve Ergen, 2013: 106). Dolayısıyla müşteri memnuniyetini arttırabilmek için, çalışanların ortaya koymuş oldukları örgütsel davranışlar dikkate alınmaktadır. ÖVD, verilen emirlere dayandırılmamış olan ve örgütlere yararlı olan davranışlardır. Ayrıca bu davranış biçimi; işletmelerde yardım etmeyi ve centilmenlik göstermeyi kapsayan rollerden meydana gelmektedir (Yıldız, 2011: 179).

ÖVD, çalışan bireylerin örgütsel düzeyde etkinliklerinin arttırılabilmesi için kendilerine verilmiş olan iş tanımlamalarının dışına çıkmak suretiyle gönüllü bir şekilde istenilenden fazlasının yapılmasını gerektirmektedir. Çalışanların işverene olan güvenleri ve yapmış oldukları işten duydukları memnuniyet, örgütsel vatandaşlık davranışı ile büyük oranda bağlantılıdır. Çalışanların örgütsel vatandaşlık davranışına aktif bir şekilde katılım göstermeleri, hizmet kalitesini de olumlu düzeyde etkilemektedir (Özcan vd., 2012: 2).

Hizmet kalitesi, çalışanların kendi işleri ile ilgili kendilerinde var olan beceri, motivasyonu ve bilgilerin tamamını gerçekleştirmesiyle oluşan örgütsel davranış biçimlerine denilmektedir (Gündüz, vd., 2007: 141). Diğer bir ifadeyle, çalışanların yapılması gereken görevlerin ya da hedeflediği amaçların yapılma dereceleri; hizmet kalitesi olarak yansımaktadır (Aylin, 2018: 67).

\subsubsection{Vicdanlılığın Hizmet Kalitesine Etkisi}

Vicdanlılık kavramı, işletmelerdeki çalışanların içsel olarak işletme kurallarını, prosedürlerini ve düzenlemelerini kabul ederek hiç kimsenin denetiminde olmasa dahi, prosedürlere ve kurallara uymasını içeren davranışlar biçimidir. Çalışanların; işletmenin kural, politika ve düzenlemelerine uymaları, vicdanlılık ilkesini benimsemeleri hizmet kalitesini etkilemekte ve tüketici memnuniyetini artırmaktadır. Vicdanlılık ilkesini benimseyen çalışanlar, kendisini denetleyen birisinin olmamasına rağmen kurallara ve düzenlemelere uyması, çalışanın iyi bir vatandaş olarak nitelendirilmesini, motivasyonunun artmasını ve hizmet kalitesinin artmasına neden olmaktadır (Organ, 1988: 44).

\subsubsection{Verimlilik ve Kalitenin, Tüketicilerin Memnuniyetini Artırmaya Etkisi}

Bireyler için yapılan iş ne derecede önemli ise işyeri ve işle ilgili algılamaları da o derecede önem arz etmektedir. İş ortamı ve iş, insan yaşamında belirleyici pek çok etki ortaya koyar. İnsanların belli bir kısmı yapmakta oldukları işi yalnızca para kazanmak için yapmamaktadır. Çalışanların yaşam kalitelerini belirlemekte olan değişkenlerin başında tüketicilerin memnuniyetini arttırmak gelmektedir. Tüketicilerin memnuniyetini artırmanın; kaliteli bir eğitim ve kaliteli bir üretim yapılmasını sağlamak ile gerçekleşebileceği ifade edilmektedir (Türkay, 2015: 239). Ürünlerin dayanıklı olması, görünüşs şekli, bakım ile tamirinin kolay olması, belirlenen amaca hizmet ediyor olması, güvenilir olması ve bütün müşterilerce önemli görülen özelliklerin tamamı kalite kapsamı içine girmektedir (Tek, 1999: 360).

Hizmet kalitesi, tüketicilerin beklentilerine karşılık verebilen, üretilen hizmetlerin, ürünlerin uygunluğudur. Verimlilik düştüğü oranda karlılık artabilir ve bu durum kısa dönem de olsa sürdürülebilir. Verimliliğin artması kısa vadede karlılık artışı sağlanamayabilir. Artmakta olan verimliliğin de karlılık üzerinde yapmış olduğu etki de uzun vadelidir. Kalite olgusu, üründen veya hizmetten beklenen ihtiyaçların giderilmesini sağlayan özelliklerin tümüne denilmektedir. Bir ürünün veya hizmetin beklenilen performans seviyesini göstermesi olarak tanımlanan kalite olgusunun, performansta gerçekleşmesi beklenen artışın, tüketici memnuniyetinde de gerçekleşeceği belirtilmektedir (Şahin, 1999: 16).

\subsection{8. Örgüt ikliminin, Çalışanları Motive Edilmesine ve Örgütsel Vatandaşlık Davranışlarına Etkisi}

ÖVD bakımından belirleyici rol oynayan faktörlerin başında; örgütün kültürü, iklim, sektör gibi örgütün içerisinde bulunan örgüt özellikleri yer almaktadır. Örgütün bulunduğu normlar ve değerler, örgütler için gerekli olan davranışsal biçimleri belirlemektedir. Örgütsel yönetime ve uygulamalara yönelik olarak ahlaki boyutları oluşturmaktadır (Arslantaş, 2008: 104). Örgütsel değerlerin kabul edilmesi, örgütlerin amaçlarına yönelik güç kullanımında artışların olmasını ve örgütlere olan istek oranlarını arttırmış olacaktır. Benzer durumda olan kurumlar, çalışanları motive ederek onların daha çok örgütsel vatandaşlık davranışları sergilemelerine destek sağlamaktadır (Clarke vd., 1991: 1149). 


\subsection{9. Örgütsel Vatandaşlık Davranışının, İşletmelerin Rekabet Ortamlarında Üstünlük Sağlamasına Etkisi}

ÖVD, işletmelerin rekabet ortamlarında üstünlük sağlaması ve gerçekleştirilmesi arzulanan amaçlarını başarılı bir şekilde gerçekleştirebilmelerinde önemli rol oynamaktadır. İnsan kaynakları yönetimi, verimlilik ve performans sorunlarının giderilmesinde, çalışanların işlerinde olumlu davranışlar sergilemelerinde önemli katkılar sağlamaktadır. ÖVD kavramı;

Yöneticiler, çalışan motivasyonunun önemini kavramalı, bireysel farklılıkları göz önünde bulundurmalı, hizmet kalitesinin sağlanması bağlamında çözümler üretebilmelidir. Bu yaklaşımları sergileyen etkili yöneticilerin örgütteki rolü pozitif yönde gelişerek, hem işletme hem de çalışanların iş performansına yansımaktadır (Bayar, 2020: 16). Gösterilen davranışlar sonucunda, fazladan çalışmaların ve çabaların yerine getirilmemesi durumlarında; herhangi bir ceza, yerine getirilmesi durumlarında ise; herhangi bir ödül bulunmamaktadır. Davranışlar, tamamen kişilerin tercihlerine bağlı olarak gerçekleştirilen davranışlar olarak ifade edilmektedir (Koçel, 2003: 423).

\section{YÖNTEM}

Bu kısımda, araştırmanın yöntemi adı altında; araştırmanın amacı, önemi, evren ve örneklemi ile araştırmada kullanılan ölçekler üzerinde durulacaktır.

\subsection{Araştırmanın Modeli ve Hipotezleri}

Nezaket davranışı ile hizmet kalitesi ilişkisine yönelik araştırma modeli SPSS analizleri sonucunda aşağıdaki şekilde şematik olarak yer almaktadır.

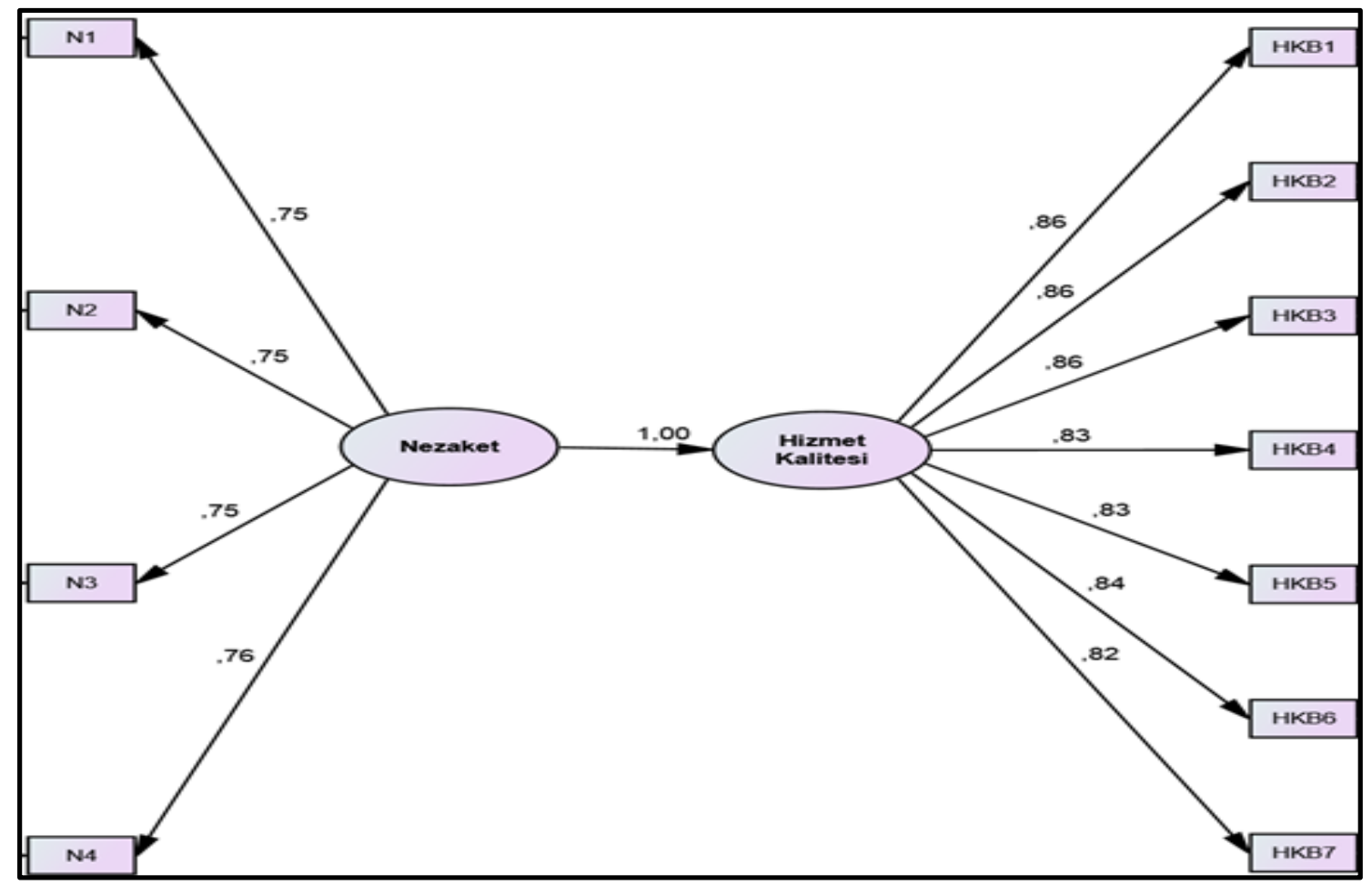

Şekil -1. Nezaket Davranışı ile Hizmet Kalitesi İlişkisine Yönelik Araştırma Modeli

Şekil 3'te SPSS uygulaması sonucunda belirlenen şematik araştırma modeline göre; nezaket davranışı için ÖVD ölçeğinden faydalanılmış ve yapılan uyum indeksleri sonucunda bulunan veriler, 4 maddeyi desteklemiştir. Ayrıca, çalışanlara dair hizmet kalitesi için "İşletme Performansı" ölçeğinden faydalanılmıştır ve uyum indeksleri göz önüne alındığında, çalışanların hizmet kalitesi alt boyutunun, mevcut bulunan 7 maddelik yapısını desteklemiş olduğu görülmektedir.

\section{Araştırmanın Hipotezleri}

H0.a: Örgütsel vatandaşlık kapsamında gösterilen nezaket tutumu ve çalışanların hizmet kalitesi seviyesinde; demografik özelliklere göre farklılık göstermez. 
H1.a: Örgütsel vatandaşlık kapsamında gösterilen nezaket tutumu ve çalışanların hizmet kalitesi seviyesinde; demografik özelliklere göre farklılık gösterir.

H0.b: Örgütsel vatandaşlık anlayışı kapsamında gösterilen nezaket davranışları ve çalışanların hizmet kalitesini etkilemez.

H1.b: Örgütsel vatandaşlık anlayışı kapsamında gösterilen nezaket davranışları ve çalışanların hizmet kalitesini etkiler.

\subsection{Araştırmanın Evren ve Örneklemi}

Araştırma için evren sayısına göre geçerli ve güvenilir örneklem büyüklüğünün tespiti için tablo-1'den yararlanılmıştır (Erdoğan ve Yazıcıoğlu, 2004: 50).

Tablo-1 Örneklem Büyüklükleri

\begin{tabular}{|c|c|c|c|c|c|c|}
\hline \multirow{2}{*}{$\begin{array}{l}\text { Evren } \\
\text { Büyüklüŭğu }\end{array}$} & \multicolumn{3}{|c|}{$\begin{array}{l}\text { +-0.05 örnekleme hatasi } \\
\text { (d) }\end{array}$} & \multicolumn{3}{|c|}{$\begin{array}{l}+0.10 \text { örnekleme hatası } \\
\text { (d) }\end{array}$} \\
\hline & $\begin{array}{l}\mathrm{p}=0.5 \\
\mathrm{q}=0.5\end{array}$ & $\begin{array}{l}\mathrm{p}=0.8 \\
\mathrm{q}=0.2\end{array}$ & $\begin{array}{l}p=0.3 \\
q=0.7\end{array}$ & $\begin{array}{l}\mathrm{p}=0.5 \\
\mathrm{q}=0.5\end{array}$ & $\begin{array}{l}\mathrm{p}=0.8 \\
\mathrm{q}=0.2\end{array}$ & $\begin{array}{l}\mathrm{p}=0.3 \\
\mathrm{q}=0.7\end{array}$ \\
\hline 1000 & 278 & 198 & 244 & 88 & 58 & 75 \\
\hline 2500 & 333 & 224 & 286 & 93 & 60 & 78 \\
\hline 5000 & 357 & 234 & 303 & 94 & 61 & 79 \\
\hline
\end{tabular}

Araştırmanın evreni; özel okullarda görev yapan yönetici öğretmen ve diğer çalışanlardan oluşan toplam 1914 kişidir. Bu çalışmanın örneklemi ise; 405 kişidir. Örneklem büyüklüğünün belirlenebilmesi için, Tablo-1 dikkate alınmıştır. Tablo dikkate alındığında, 1914 evren büyüklüğü için tablodan 2500 kişiye kadar evreni kapsayan 333 kişinin örneklem olarak alınmıştır. Güvenilirliğin sağlanabilmesi için, örneklem miktarı 450 kişi olarak alınmasını yeterli olacağı kararı verilmiş ve yapılan anket uygulaması sonucunda 45 anket hatalı ve eksik olduğundan iptal edilerek geriye kalan 405 anket geçerli olarak kabul edilmiştir. Anketler, tesadüfi örnekleme yöntemiyle 25 Ekim 2019 ve 15 Aralık 2019 tarihleri arasında yapılmıştır. Bu tarihler özel okullarda görev yapan yönetici, öğretmen ve diğer çalışanların mesai saatleri araştırılarak mesai saatleri dışında gerçekleştirilmiştir.

\subsection{Veri Toplama Aracı}

$\mathrm{Bu}$ araştırmada verilerin elde edilmesi için "demografik bilgilerle ilgili sorular", "Örgütsel Vatandaşlık Davranışı Ölçeği" ve "İşletme Performansı Ölçeği" nden yararlanılmış ve ölçeklerle ilgili açıklamalar aşağıda belirtilmiştir;

\section{1- Örgütsel Vatandaşlık Davranışı Ölçeği;}

Bu çalışmada, Padsakoff ve Mackenzie'nin (1989) geliştirdiği, Mehtap (2011) tarafından da Türkçeye adapte edilen, sonra Yılmaz'ın (2018) araştırmasında yer alan "Örgütsel Vatandaşlık Davranışı Ölçeği”nden yararlanılmıştır. Örgütsel Vatandaşlık Davranışı Ölçeği; 4 boyuttan meydana gelmektedir. Katılımcıların anketlerde bulunan sorulara; $5=$ kesinlikle katıliyorum, 4=katıliyorum, 3=kararsızım, $2=$ katılmıyorum ve 1=kesinlikle katılmıyorum şeklinde cevaplandırabilecekleri 5'li likert tipi ölçek kullanılmıştır. ÖVD ölçeğinin güvenilirlik katsayısı ise; 0,813 olarak bulunmuştur.

\section{2- İşletme Performansı Ölçeği;}

Bu çalışmada, Fitzgerald vd.'nin (1991) geliştirmiş olduğu, Brignall ve Ballantine (1996) ile Atkinson ve Brown'un (2001) çalışmalarında bulunan "İşletme Performansı Ölçeği" kullanılmıştır. İşletme Performansı Ölçeği; hizmet kalitesi boyutu 7 madde'den meydana gelmektedir. Katılımcıların anketlerdeki sorulara; $5=$ kesinlikle katıliyorum, 4=katıliyorum, 3=kararsızım, $2=$ katılmıyorum ve $1=$ kesinlikle katılmiyorum diye cevaplandırabilecekleri 5'li likert tipi ölçek kullanılmıştır. İşletme performansı ölçeğinin güvenilirlik katsayısı, 0,83 olarak bulunmuştur. 


\subsection{Verilerinin Analizi}

Bu araştırmada; neden sonuç ilişkisini ortaya koyacak niceliksel yöntem tekniği esas alınmış, belirlenen anket soruları, ilgili katılımcılara dağıtılmış ve analiz için gerekli veriler elde edilmiştir. Elde edilen veriler SPSS istatistik programı uygulanarak; güvenilirlik analizleri, doğrulayıcı faktör analizleri, T-testi, ANOVA, korelasyon ve regresyon analizleri yapılarak bulgular, sonuç ve öneriler bölümleri tamamlanmıştır.

\section{BULGULAR}

Bu kısımda güvenilirlik analizi, doğrulayıcı faktör analizi, demografik bulgular, t-testi, one way anova analizi, korelasyon analizi ve regresyon analizlerine yönelik bulgular yer almaktadır.

\section{1. Örgütsel Vatandaşlık Faktörlerinden Nezaket Davranışı İçin Güvenilirlik Analizi ve Doğrulayıcı Faktör Analizi}

Örgütsel vatandaşlık faktörlerinden biri olan nezaket davranışını var eden grubun yapısı (4 madde) doğrulayıcı faktör analizi (DFA) ile test edilmiştir. İlk adımında, model uyum indekslerinin uygun aralıklarda değer alıp almadığı $(p<0,05)$ bulunmuştur.

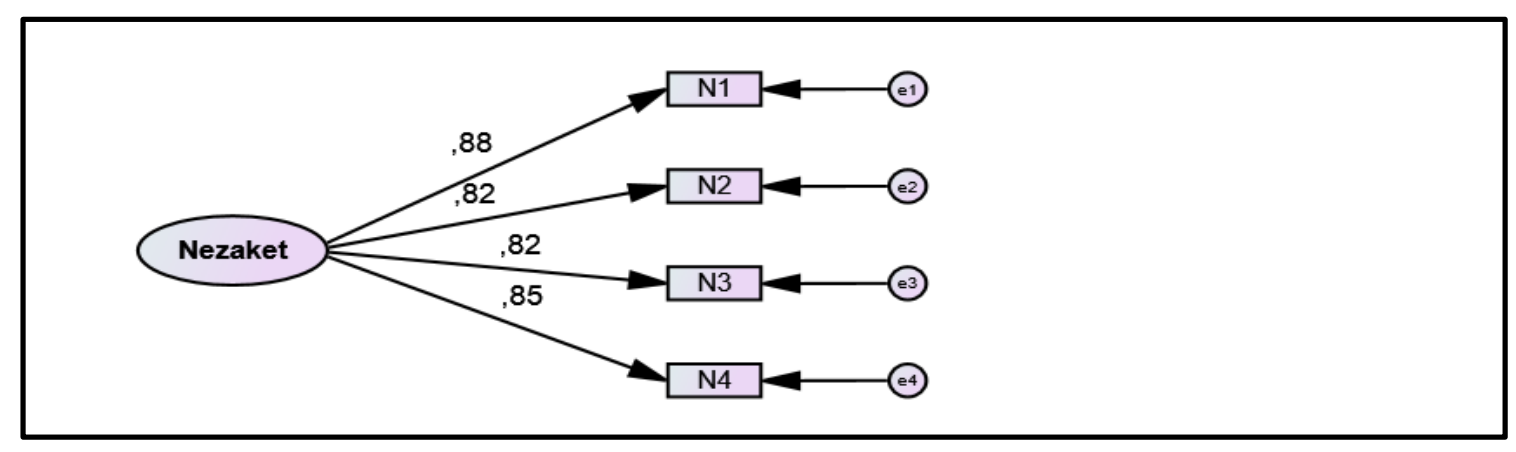

Şekil -2. Örgütsel Vatandaşlık Faktörlerinden Nezaket Davranışı İçin DFA

Testi yapılan modelin, örgütsel vatandaşlık faktörlerinden biri olan nezaket davranışı "Nezaket" ile gösterilmektedir. Ayrıca modelde e1, e2, e3 ve e4 ile belirtilen yapılar, hata terimleri olarak yer bulmuştur.

Doğrulayıcı faktör analizi uygulaması yapılırken örgütsel vatandaşlık faktörlerinden biri olan nezaket davranışının N1, N2, N3, N4 olmak üzere 4 madde ile tanımlanması uygun görülmüştür.

Tablo-2 Örgütsel Vatandaşlık Faktörlerinden Nezaket Davranışının Model Uyum İndeksleri

\begin{tabular}{lccc}
\hline & İyi Değer & Uygun Değer & Hesaplanan Değer \\
\hline $\mathbf{X}^{2} / \mathbf{s d}$ & 3' $^{\prime}$ den Küçük & $5^{\prime}$ den Küçük & 1,688 \\
\hline RMSEA & 0,050 ve daha Düşük & 0,080 ve daha Düşük & 0,041 \\
\hline GFI & 0,90 ve Yüksek & 0,85 ve Yüksek & 0,996 \\
\hline NFI & 0,90 ve Yüksek & 0,85 ve Yüksek & 0,997 \\
\hline CFI & 0,95 ve Yüksek & 0,90 ve Yüksek & 0,998
\end{tabular}

Örgütsel vatandaşlık faktörlerinden birisi olan nezaket davranışı için model uyum indeksleri tablosundaki değerler göz önüne alındığında, model uyum indeks sonuçları iyi bir seviyededir.

\section{2. Çalışanların Hizmet Kalitesi İçin Güvenilirlik Analizi ve Doğrulayıcı Faktör Analizi}

Çalışanların Hizmet Kalitesini oluşturan grubunun yapısı (7 madde) doğrulayıcı faktör analizi (DFA) kullanılarak test edilmiştir. İlk adımda model uyum indekslerinin uygun aralıklarda değer alıp almadığına $(\mathrm{p}<0,05)$ bakılmıştır.

Doğrulayıı faktör analizi modelinde Çalışanların Hizmet Kalitesi HKB1, HKB2, HKB3, HKB4, HKB5, HKB6, HKB7 olarak 7 madde ile açıklanmıştır. 


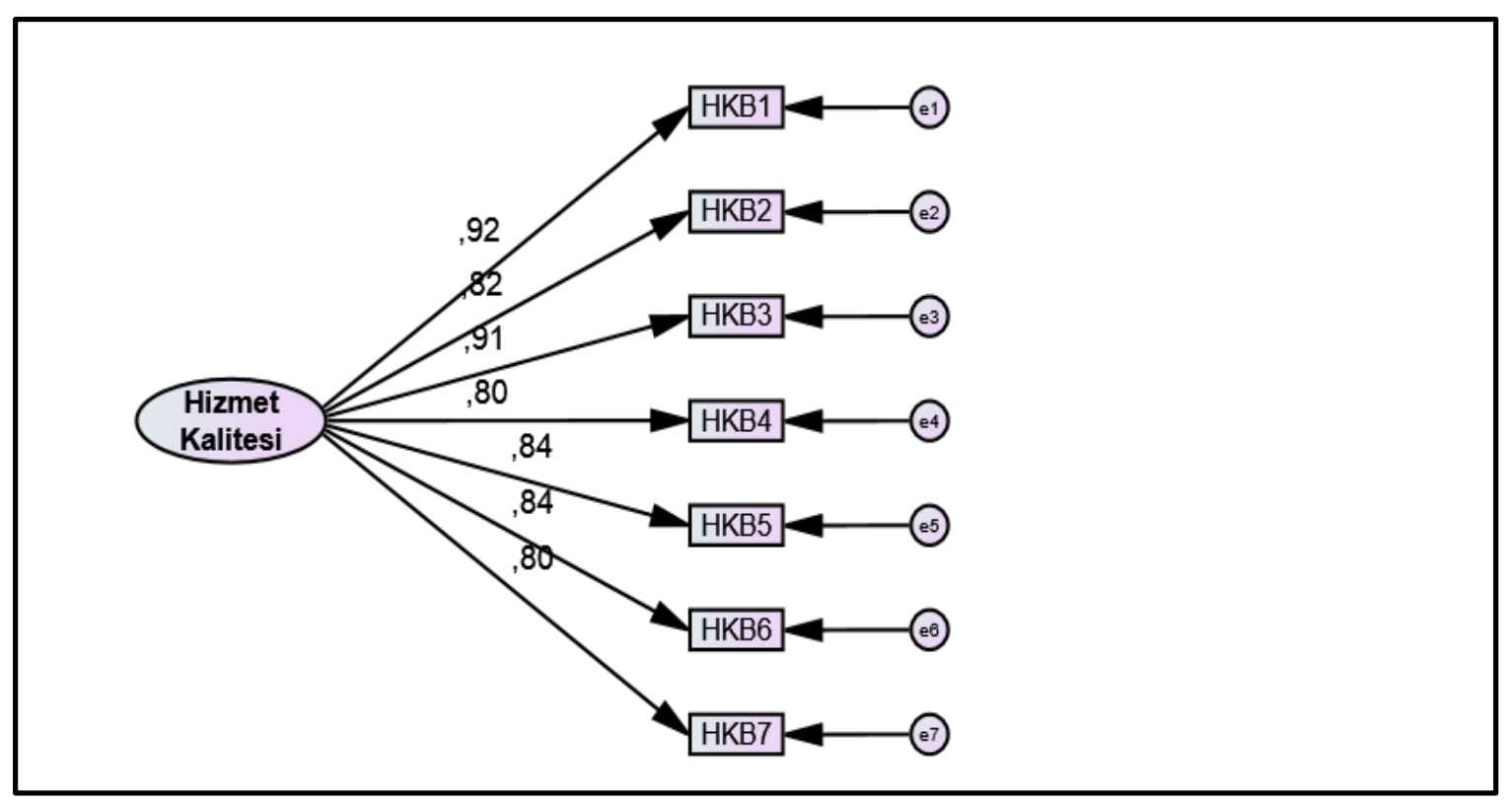

Şekil -3. Çalışanların Hizmet Kalitesi İçin DFA

Test edilen modelde çalışanların hizmet kalitesi “Hizmet Kalitesi” ile gösterilmiştir. Ayrıca modelde e1, e2, e3 ve e4 ile gösterilen yapılar ise, hata terimleridir.

Doğrulayıcı faktör analizi modelinde çalışanların hizmet kalitesi HKB1, HKB2, HKB3, HKB4, HKB5, HKB6, HKB7 olmak üzere 7 madde ile tanımlamak amaçlanmıştır.

Tablo-3 Çalışanların Hizmet Kalitesinin Model Uyum İndeksleri

\begin{tabular}{lccc}
\hline & İyi Değer & Uygun Değer & Hesaplanan Değer \\
\hline $\mathbf{X}^{2} / \mathbf{s d}$ & 3'den Küçük & 5'den Küçük & 2,358 \\
\hline RMSEA & 0,050 ve daha Düşük & 0,080 ve daha Düşük & 0,044 \\
\hline GFI & 0,90 ve Yüksek & 0,85 ve Yüksek & 0,997 \\
\hline NNFI & 0,90 ve Yüksek & 0,85 ve Yüksek & 0,992 \\
\hline CFI & 0,95 ve Yüksek & 0,90 ve Yüksek & 0,989
\end{tabular}

Çalışanların hizmet kalitesi için Model Uyum İndeksleri tablosundaki değerlere bakıldığında, model uyum indekslerinin genel olarak iyi bir seviyede bulunduğu tespit edilmiştir.

Tablo-4 Tahmin Değerleri

\begin{tabular}{|c|c|c|c|c|}
\hline Boyut & Madde & $\begin{array}{l}\text { Tahmin } \\
\text { Değeri }\end{array}$ & $\begin{array}{l}P \\
\text { değeri }\end{array}$ & Cronbach $\alpha$ \\
\hline \multirow{3}{*}{ 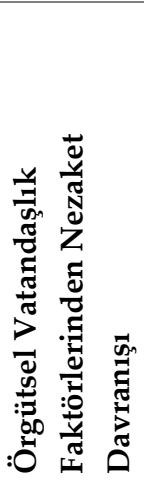 } & $\begin{array}{l}\text { 1. Herhangi bir karar verirken bundan etkilenebilecek } \\
\text { üstümün ve başka çalışanların düşüncelerini sorarım. }\end{array}$ &, 878 & $* * *$ & \multirow{3}{*}{0,905} \\
\hline & $\begin{array}{l}\text { 2. İşimle ilgili önemli bir adım atmadan önce ilgili kişilere } \\
\text { bilgi veririm. }\end{array}$ & 818 & $* * *$ & \\
\hline & $\begin{array}{l}\text { 3. Başka çalışanların karşılaşabileceği problemleri önlemek } \\
\text { ve mevcut problemlerine çare bulmak maksadıyla yardımcı } \\
\text { olurum. }\end{array}$ & 819 & $* * *$ & \\
\hline
\end{tabular}




\begin{tabular}{|c|c|c|c|c|}
\hline & 4. Diğer çalışanların haklarına saygı gösteririm. & 845 & $* * *$ & \\
\hline \multirow{7}{*}{ 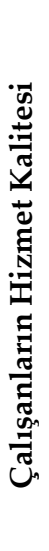 } & $\begin{array}{l}\text { 1. Güvenilirlik, hızlı cevap verebilme işletme performansını } \\
\text { etkiler. }\end{array}$ & ,916 & $* * *$ & \multirow{7}{*}{0,948} \\
\hline & 2. Estetik / görünüm, işletme performansını etkiler. & 824 & *** & \\
\hline & $\begin{array}{l}\text { 3. Temizlik / düzenlilik, konfor, işletme performansını } \\
\text { etkiler. }\end{array}$ & ,906 & $* * *$ & \\
\hline & 4. Samimiyet, iletişim, işletme performansını etkiler. & ,802 & $* * *$ & \\
\hline & 5. Nezaket, yetkinlik, erişim, işletme performansını etkiler. & ,838 & $* * *$ & \\
\hline & 6. Ulaşılabilirlik, işletme performansını etkiler. & 841 & $* * *$ & \\
\hline & 7. Güvenlik, işletme performansını etkiler. & 800 & $* * *$ & \\
\hline
\end{tabular}

$* * *=\mathrm{P}<0,001$

Nezaket davranışı için anket soruları belirlenirken, Örgütsel Vatandaşlık Davranışı ölçeğinden faydalanılmıştır. Analizin neticesinde bulunan uyum indeksleri göz önüne alındığında, yapılan saha çalışması sonucunda bulunan verilerin, nezaket davranışı alt boyutunun, mevcut 4 maddelik yapısını desteklediği fark edilmektedir.

Nezaket Davranışı tanımlaması, hedeflenen her bir soruya ait $p$ değerinin anlamlı olduğu tespit edilmiştir $(\mathrm{p}<0,01)$. Yanı sıra, sorulara dair tahmin değerlerinin de oldukça yüksek seviyede olduğu bulunmuştur. Nezaket davranışı için hesaplanan Cronbach Alfa değeri 0,905'tir. Sonuç olarak, nezaket davranışının yüksek güvenilirlik derecesinde bulunduğu görülmektedir.

Çalışanlara dair hizmet kalitesi anket soruları elde edilirken, işletme performansı ölçeğinden faydalanılmıştır (Atkinson ve Brown, 2001: 130). Analizin neticesinde de bulunan uyum indeksleri göz önüne alındığında, yapılan saha araştırması neticesinde bulunan verilerin, çalışanların hizmet kalitesi alt boyutunun mevcut bulunan 7 maddelik yapısını desteklediği fark edilmektedir. Çalışanların hizmet kalitesini tanımlaması hedeflenen her bir soruya dair $p$ değerinin anlamlı olduğu bulunmuştur $(p<0,01)$. Yanı sıra, anket sorularına dair tahmin değerleri de yüksek değerler almışlardır. Çalışanların hizmet kalitesi için hesaplanan Cronbach Alfa değeri 0,948 'dir. Bu değerin seviyesi, çalışanların hizmet kalitesinin yüksek güvenilirlikte olması anlamina gelmektedir.

\subsection{Demografik Bulgular}

Bu çalışmada, cinsiyet, yaş, medeni durum ve eğitim durumu gibi demografik değişkenlerin dağılımları, betimleyici istatistikler kullanılarak araştırılmıştır.

Tablo-5 Demografik Değişkenlerin Frekans Tablosu

\begin{tabular}{|l|l|c|c|}
\hline \multicolumn{2}{|c|}{} & Frekans & Yüzde \\
\hline \multirow{3}{*}{ Cinsiyet } & Kadın & 248 & $61,2 \%$ \\
\cline { 2 - 4 } & Erkek & 157 & $38,8 \%$ \\
\hline \multirow{4}{*}{ Yaş } & $18-23$ Yaş & 34 & $8,4 \%$ \\
\cline { 2 - 4 } & $24-29$ Yaş & 176 & $43,5 \%$ \\
\cline { 2 - 4 } & $30-35$ Yaş & 110 & $27,2 \%$ \\
\cline { 2 - 4 } & $36-41$ Yaş & 67 & $16,5 \%$ \\
\cline { 2 - 4 } & 42 Yaş ve Üzeri & 18 & $4,4 \%$ \\
\hline \multirow{3}{*}{ Medeni Durum } & Evli & 267 & $65,9 \%$ \\
\cline { 2 - 4 } & Bekâr & 138 & $34,1 \%$ \\
\hline \multirow{3}{*}{ ğititim Durumu } & İlköğretim & 23 & $5,7 \%$ \\
\cline { 2 - 4 } & Ön Lisans & 76 & $18,8 \%$ \\
\cline { 2 - 4 } & Lisans & 239 & $59,0 \%$ \\
\cline { 2 - 4 } & Yüksek lisans veya Doktora & 67 & $16,5 \%$ \\
\hline
\end{tabular}


Betimleyici istatistikleri belirlemek için yapılan frekans analizi sonuçlarına bakıldığında toplam 405 kişiden; 157 kişinin erkek $(\% 38,8)$ ve 248 kişinin ise, kadın $(\% 61,2)$ olduğu gözlenmiştir. Katılımcıların yaş dağılımlarına bakıldığında; 18-23 yaş arasında 34 kişi $(\% 8,4)$, 24-29 yaş arasında 176 (\%43,5) kişi ve $30-35$ yaş arasında, $110(\% 27,2)$ kişi, 36-41 yaş arasında, 67 kişi $(\% 16,5)$ ve 42 yaş üstü $18(\% 4,4)$ kişinin olduğu gözlenmiştir. Katılımcıların 267'sinin evli $(\% 65,9)$ 138'inin ise bekâr $(\% 34,1)$ olduğu görülmektedir. Ayrıca, araştırmaya katılan kişilerin 23'ünün ilköğretim (\%5,7), 76'sının ön lisans (\%18,8), 239'unun lisans (\%59,0) ve 67 'sinin ise yüksek lisans veya doktora $(\% 16,5)$ düzeyinde eğitim aldıkları tespit edilmiştir.

\subsection{Demografik Özellikler ile Örgütsel Vatandaşlık Faktörlerinden Nezaket Davranışının ve Çalışanların Hizmet Kalitesi Arasındaki İlişki İçin T-Testi ve F-Testi}

Bu tezde, veri analizi yöntemini seçebilmek adına, ilk adımda verilerin normal dağılımda olduğunun tespit edilmesi gerekmektedir. Bunun için bulunan, basıklık ve çarpıklık katsayısından faydalanılmıştır. Yapılan analizler neticesinde veri yapısının normal dağılıma uygun bulunduğu ve parametrik test yöntemlerinin kullanılmasının uygun olduğu tespit edilmiştir.

Yapılması öngörülen testlerde değişkenlerin 2 gruptan oluştuğu hallerde; $t$ testinden ve ikiden fazla gruptan oluştuğu durumlarda ise; $f$ testinden (one way anova) faydalanılmıştır. Testin nihayetinde, karar verirken $p$ değeri dikkate alınmıştır. Hesaplanan $p$ değeri alfa (Alpha=0,05) değerinden daha küçük ise, farklılığın bulunduğu ve büyük olduğu durumlarda ise, farklılığın olmadığı sonucuna ulaşılmıştır.

Demografik Özellikler İle Örgütsel Vatandaşlık Faktörlerinden Nezaket Davranışı ve Çalışanların Hizmet Kalitesi Arasındaki İlişki

Demografik özellikler ile örgütsel vatandaşlık faktörlerinden nezaket davranışı ve çalışanların hizmet kalitesi arasındaki ilişki t- testi ve f testi yardımıyla incelenmiştir.

Tablo-6 Demografik Özellikler ile Örgütsel Vatandaşlık Faktörlerinden Nezaket Davranışının ve Çalışanların Hizmet Kalitesi Arasındaki İlişki İçin T-Testi ve F-Testi Tablosu

\begin{tabular}{|c|c|c|c|c|c|c|c|}
\hline Düzeyler & & & $\mathbf{N}$ & Ort. & $\begin{array}{l}t \text { veya } f \\
\text { Değeri }\end{array}$ & $\begin{array}{c}p \\
\text { Değeri }\end{array}$ & Hipotez/ Post Hoc \\
\hline \multirow{4}{*}{ Cinsiyet } & \multirow{2}{*}{ Nezaket } & Kadın(a) & 248 & 3,9073 & \multirow{2}{*}{$-8,953$} & \multirow{2}{*}{, 000} & \multirow{2}{*}{$\begin{array}{c}\mathrm{A}>\mathrm{B} \\
\mathrm{H} 1 \text { kabul }\end{array}$} \\
\hline & & Erkek(b) & 157 & 4,4920 & & & \\
\hline & \multirow{2}{*}{$\begin{array}{l}\text { Hizmet } \\
\text { Kalitesi }\end{array}$} & Kadın(a) & 248 & 4,0426 & \multirow{2}{*}{$-5,445$} & \multirow{2}{*}{, 000} & \multirow{2}{*}{$\mathrm{A}>\mathrm{B}$} \\
\hline & & Erkek(b) & 157 & 4,4331 & & & \\
\hline \multirow{10}{*}{ Yaş } & \multirow{5}{*}{ Nezaket } & 18-23 Yaş(a) & 34 & 4,1985 & \multirow{5}{*}{5,003} & \multirow{5}{*}{,001 } & \multirow{5}{*}{$\begin{array}{l}\mathrm{e}>\mathrm{a}, \mathrm{b}, \mathrm{c}, \mathrm{d} \\
\mathrm{H} 1 \mathrm{kabul}\end{array}$} \\
\hline & & 24-29 Yaş(b) & 176 & 4,1051 & & & \\
\hline & & 30-35 Yaş(c) & 110 & 4,1341 & & & \\
\hline & & 36-41 Yaş(d) & 67 & 3,9851 & & & \\
\hline & & 42 Yaş ve Üzeri(e) & 18 & 4,8472 & & & \\
\hline & \multirow{5}{*}{$\begin{array}{l}\text { Hizmet } \\
\text { Kalitesi }\end{array}$} & 18-23 Yaş(a) & 34 & 4,2353 & \multirow{5}{*}{3,368} & \multirow{5}{*}{,010 } & \multirow{5}{*}{$\begin{array}{l}\mathrm{e}>\mathrm{a}, \mathrm{b}, \mathrm{c}, \mathrm{d} \\
\mathrm{H} 1 \mathrm{kabul}\end{array}$} \\
\hline & & 24-29 Yaş(b) & 176 & 4,1672 & & & \\
\hline & & 30-35 Yaş(c) & 110 & 4,1662 & & & \\
\hline & & 36-41 Yaş(d) & 67 & 4,1173 & & & \\
\hline & & 42 Yaş ve Üzeri(e) & 18 & 4,8333 & & & \\
\hline \multirow{4}{*}{$\begin{array}{l}\text { Medeni } \\
\text { Durum }\end{array}$} & \multirow{2}{*}{ Nezaket } & Evli & 267 & 4,1320 & \multirow[t]{2}{*}{,- 072} & \multirow[t]{2}{*}{,943 } & \multirow{2}{*}{ H1 Red } \\
\hline & & Bekâr & 138 & 4,1377 & & & \\
\hline & \multirow{2}{*}{$\begin{array}{l}\text { Hizmet } \\
\text { Kalitesi }\end{array}$} & Evli & 267 & 4,1915 & \multirow{2}{*}{,- 088} & \multirow{2}{*}{,930 } & \multirow{2}{*}{ H0 Kabul } \\
\hline & & Bekâr & 138 & 4,1988 & & & \\
\hline \multirow{8}{*}{$\begin{array}{l}\text { Eğitim } \\
\text { Durumu }\end{array}$} & \multirow{4}{*}{ Nezaket } & İlköğretim(a) & 23 & 3,2826 & \multirow{4}{*}{12,720} & \multirow{4}{*}{, 000} & \multirow{4}{*}{$\begin{array}{c}\mathrm{a}<\mathrm{b}, \mathrm{c}, \mathrm{d} \\
\mathrm{H} 1 \text { kabul }\end{array}$} \\
\hline & & Ön Lisans(b) & 76 & 4,0658 & & & \\
\hline & & Lisans(c) & 239 & 4,2437 & & & \\
\hline & & Yüksek lisans veya & 67 & 4,1119 & & & \\
\hline & & İlköğretim(a) & 23 & 3,7205 & & & \\
\hline & & Ön Lisans(b) & 76 & 4,0959 & & & $\mathrm{a}<\mathrm{c}, \mathrm{d}$ \\
\hline & $\begin{array}{l}\text { H1zmet } \\
\text { Kalitesi }\end{array}$ & Lisans $(c)$ & 239 & 4,2648 & 3,980 &, 008 & H1 kabul \\
\hline & & $\begin{array}{l}\text { Yüksek lisans veya } \\
\text { Doktora (d) }\end{array}$ & 67 & 4,2154 & & & \\
\hline
\end{tabular}


$\mathrm{H}_{0 . a:}$ Örgütsel vatandaşlık kapsamında gösterilen nezaket tutumu ve çalışanların hizmet kalitesi seviyesinde; demografik özelliklere göre farklılık göstermez.

H.a: Örgütsel vatandaşlık kapsamında gösterilen nezaket tutumu ve çalışanların hizmet kalitesi seviyesinde; demografik özelliklere göre farklılık gösterir.

Demografik değişkenlere göre farklılıkların tespiti için yapılan testler sonucunda; cinsiyet değişkeni için H1 hipotezinin nezaket $(\mathrm{p}=0,00)$ ve hizmet kalitesi $(\mathrm{p}=0,00)$ için kabul edildiği tespit edilmiştir $(\mathrm{p}<0,05)$. Bu sonuçlara bakılarak, nezaket ve hizmet kalitesinin cinsiyete göre farklılık gösterdiği söylenebilir. Ortalama değerleri incelendiğinde, erkeklerin nezaket ve hizmet kalitesinin kadınlara göre daha yüksek olduğu görülmektedir.

Yaşa göre farklılık için hesaplanan $p$ değerleri incelendiğinde, nezaket $(\mathrm{p}=0,001)$ ve hizmet kalitesi $(\mathrm{p}=0,010)$ için H1 hipotezinin kabul edildiği görülmüştür. Bu sonuçlara bakarak, nezaket ve hizmet kalitesinin yaşa göre farklılık gösterdiği söylenebilir. Ortalama değerleri incelendiğinde, 42 yaş üzerinde olan kişilerin nezaket ve hizmet kalitesi ortalamalarının diğer yaş gruplarına göre daha yüksek olduğu tespit edilmiştir.

Medeni duruma göre farklılık için hesaplanan $p$ değerleri incelendiğinde, nezaket $(p=0,943)$ ve Hizmet Kalitesi $(p=0,930)$ için $\mathrm{H} 0$ hipotezinin kabul edildiği görülmüştür. Bu değerlere bakılarak, nezaket ve hizmet kalitesinin medeni duruma göre farklılık göstermediği söylenebilir.

Eğitim durumuna göre farklılık için hesaplanan $p$ değerleri incelendiğinde, nezaket $(p=0,943)$ ve hizmet kalitesi $(\mathrm{p}=0,930)$ için $\mathrm{H} 1$ hipotezinin kabul edildiği görülmüştür. Bu değerlere bakılarak, nezaket ve hizmet kalitesinin eğitim durumuna göre farklılık gösterdiği söylenebilir. Ortalama değerleri incelendiğinde, ilköğretim düzeyinde eğitim almış kişilerin nezaket ve hizmet kalitesi ortalamalarının diğer eğitim durumlarına göre daha düşük olduğu tespit edilmiştir.

Demografik değişkenlerin özel okullardaki oranlarına bakıldığında, yaş ve cinsiyet faktörleri açısından karşılaştırma yapıldığında, farklı olduğu bulgularına ulaşılmıştır. Öte yandan, evli olanların bekar olanlara oranla sayısının fazla olduğu gözlenmekle beraber eğitim seviyelerinde lisans mezunu olanların oranın oldukça yüksek olduğu, peşi sıra; ön lisans, ilköğretim, yüksek lisans ve doktora diye azalarak devam etmektedir. İlköğretim düzeyindeki çalışanlar dikkat çekmekle birlikte performansa etkilerinin büyük oranda olmadığı, uzmanlaşmanın negatif etkilerinin azaldığı görülmektedir. Eğitim seviyesi yüksek çalışanların, her boyutta pozitif yönlü etkilerinin olduğu gözlenmiştir. Demografik değişkenlere bakılmaksızın hizmet içi eğitimlerin periyodik olarak yapılmasının, çalışanların uzmanlaşması, farkındalıklarının ve motivasyonlarının artırılması bakımından etkilerinin oldukça fazla olduğu, bu kapsamda çalışmaların devamlı yapılması gerekli olmaktadır.

\subsection{Korelasyon Analizi}

Korelasyon analizi yalnız 2 değişken arasındaki doğrusal ilişkiyi gösteren istatistiksel bir araştırma yöntemidir. Bu yöntem ile, değişkenler arasındaki ilişkinin büyüklüğü ve yönü bulunmaktadır.

Korelasyon katsayısı $\mathrm{r}$ ile gösterilmektedir. Aldığı değer aralığ $1-1<\mathrm{r}<1$ arasındadır. Korelasyon katsayısı değeri uç nokta değerleri olan -1 ve 1 değerine yaklaştıkça değişkenler arasındaki ilişkinin seviyesi artar. Korelasyon değerinin negatif (-) veya pozitif (+) değerde bulunması ilişkinin yönünü belirler, 0'a yakın değerde olması değişkenler arasında ilişkinin bulunmadığı anlamına gelmektedir

Tablo-7 Korelasyon Değer Aralıkları

\begin{tabular}{l|c}
\hline Değer Aralığı & Illişki Büyüklüğ̈̈ \\
\hline$-0,2<\mathrm{r}$ veya $\mathrm{r}<0,2$ & Çok Zayıf \\
\hline$-0,4<\mathrm{r}-<-0,2$ veya $0,2<\mathrm{r}<0,4$ & Zayıf \\
\hline$-0,6<\mathrm{r}-<-0,4$ veya $0,4<\mathrm{r}<0,6$ & Orta \\
\hline$-0,8<\mathrm{r}-<-0,6$ veya $0,6<\mathrm{r}<0,8$ & Yüksek \\
\hline$-1<\mathrm{r}-<-0,8$ veya $0,8<\mathrm{r}<1$ & Çok Yüksek \\
\hline
\end{tabular}


Korelasyon analizi neticesinde $r$ katsayısı göz önüne alınarak değerlendirme yapılırken değişkenler arasındaki neden sonuç ilişkisi ile ilgili değerlendirme yapılamaz. Çünkü korelasyon analizinde hangi değişkenin diğerine tesir ettiği değerlendirmesi yapılamamaktadır.

Tablo-8 Korelasyon Analizi

\begin{tabular}{l|c|c}
\hline & Nezaket & Hizmet Kalitesi \\
\hline Nezaket & 1 &, $778^{* *}$ \\
\hline Hizmet Kalitesi &, $778^{* *}$ & 1 \\
\hline
\end{tabular}

Nezaket ile hizmet kalitesi arasındaki korelasyon katsayısı 0,778' dir. Bu korelasyon değerinin anlamı, Nezaket ile hizmet kalitesi arasında pozitif yönlü bir ilişkinin varlığıdır. İlişkinin büyüklüğünü ve yönünü belirleyebilmek için korelasyon analizi yetersiz kaldığından regresyon analizi uygulamak daha doğrudur.

\subsection{Regresyon Analizi}

Regresyon analizi, bir bağımlı değişken üzerindeki en az bir bağımsız değişkenin tesirini bulmak için kullanılmaktadır. Bu analiz yöntemi ile doğrusal ilişkinin varlığı, büyüklüğü ve yönü tespit edilmektedir. Regresyon analizi ile değişkenler arasındaki ilişki test edilirken matematiksel bir denklemden faydalanılmaktadır. İlişkinin yönü ve büyüklüğü bu denklemde beta değerleri ile gösterilmektedir.

Regresyon analizi ile kurulan modelin teorik yapısı; $Y=\beta_{0}+\beta_{i} X_{i}+\varepsilon_{i}$ şeklinde gösterilmektedir. Bu denklemde verilen $X_{i}$ i. bağımsız değişkeni, $Y$ bağımlı değişkeni, $\beta_{i}$ i. bağımsız değişkene ait katsayıyı, $\varepsilon_{i}$ ise i. bağımlı değişkene sahip hata terimlerini ve $\beta_{0}$ sabit katsayı değerini ifade etmektedir

\section{Örgütsel Vatandaşlık Faktörlerinden Nezaket Davranışının, Çalışanların Hizmet Kalitesine Etkileri}

Tablo-9 Örgütsel Vatandaşlık Faktörlerinden Nezaket Davranışının ve Çalışanların Hizmet Kalitesi Arasındaki İlişki

\begin{tabular}{lccc}
\hline & \multicolumn{3}{c}{ Hizmet Kalitesi } \\
\hline Sabit Katsayı & $\beta($ Beta) & t Değeri & p Değeri \\
\hline Nezaket &, 863 & 6,337 &, 000 \\
\hline
\end{tabular}

Ho.b: Örgütsel vatandaşlık anlayışı kapsamında gösterilen nezaket davranışları ve çalışanların hizmet kalitesini etkilemez.

H1.b: Örgütsel vatandaşlık anlayışı kapsamında gösterilen nezaket davranışları ve çalışanların hizmet kalitesini etkiler.

Yapılan regresyon analizi neticesinde sabit katsayı $(p=0,00)$ ve Nezaketin $(p=0,806)$ Hizmet Kalitesini istatistiksel olarak anlamlı bir seviyede etkilediği bulunmuştur $(\mathrm{p}<0,05)$. Bu sebeple kurulacak olan regresyon denklemi modeline, ilişkileri anlamlı olduğu tespit edilen değişkenler alınmıştır.

$Y=\beta_{0}+\beta_{i} X_{i}$ şeklinde kurulacak olan denklem için aralarındaki ilişkinin anlamlı olduğu bulunan düzey sayısı iki olduğu için $i=1$ olarak alınmaktadır. Bulunan denklemin teorik yapısı $Y=\beta_{0}+\beta_{1} X_{1}$ şeklindedir. Bu denklemde kullanılan sembollerin anlam ve karşılıkları aşağıdaki regresyon sembollerinin karşılıkları tablosunda gösterilmektedir.

Tablo-10 Regresyon Sembollerinin Karşılıkları

\begin{tabular}{cll}
\hline Semboller & Anlamları & Karşılık Gelen Kavram/Değer \\
\hline $\mathbf{Y}$ & Bağımlı Değişken & Hizmet Kalitesi \\
\hline $\mathbf{X}_{\mathbf{1}}$ & Bağımsız Değişken & Nezaket \\
\hline$\beta_{\mathbf{0}}$ & Sabit Katsayı & 0,863 (Tablodaki B değerlerinden) \\
\hline$\beta_{1}$ & Bağımsız Değişkene ait Katsayı & 0,806 \\
\hline
\end{tabular}


Regresyon sembollerinin karşılıkları tablosundaki sembol karşılıkları ve değerler denklemde yerini bulduğunda denklemin son durumu şöyle gösterilmektedir.

Hizmet Kalitesi $=0,863+0,806$ Nezaket

Yapılan regresyon analizi için uygulanan denklem sonucunda okullarda gösterilen nezaketin, hizmet kalitesi üzerinde pozitif yönde bir etkisi olduğu tespit edilmiştir. Oluşturulan denklemde, nezaket puanının bir birim arttığ1 durumda, hizmet kalitesi puanının 0,806 birim artacağı görülmektedir. Bu nezaketin hizmet kalitesi üzerinde yaklaşık \%80,6 oranında pozitif yönlü bir tesiri olduğu anlamına gelmektedir.

\section{TARTIŞMA}

Örgütsel vatandaşlık faktörlerinden nezaket davranışının ve çalışanların hizmet kalitesinin; demografik özellikleri arasında farklılıkları olduğu tespit edilmiştir. Bulgular sonucunda, nezaket ve hizmet kalitesinin kadınlara oranla erkeklerde daha fazla olduğu görülmektedir. Sökmen'in yapmış olduğu araştırmada ise cinsiyet değişkenleri incelendiğinde, kadınların nezaket konusunda düşük tutum ve davranışlar göstermesinin nedeni; kendilik algılamaları, kişisel değerlerinin tutum ve davranışlarına yansıması olarak görülebilir. ÖVD boyutlarından "nezaket" incelendiğinde, erkek ve kadın çalışanların geribildirimleri arasında anlamlı farklılık bulunduğu görülmüştür. Fakat kadın çalışanların, bu boyutlara dair verdikleri geribildirim ve görüşler, erkeklere kıyasla daha olumlu bulunmuştur (Sökmen, 2011: 157). Diğer taraftan Köse'nin çalışmasında; Otel işletmelerinin sınır birimlerinde görev yapan kadın çalışanların, erkek çalışanlara göre daha özgeci ve kibar tavırlar gösterdikleri fark edilmiştir(Köse, vd., 2003: 17).

Bu çalışmada yapılan anova analizi soncunda, 42 yaş üzerindeki örgüt çalışanlarının nezaket tutum ve davranışının, pozitif yönlü olduğu sonucuna ulaşılmıştır. Bu sonuca göre; yaş dağılımları ele alındığında büyük oranda farklılıkların olduğu gözlenmiştir. Karacaoğlu ve Güney yaptıkları araştırmada ise örgütsel bağl1lık veya başka bir deyişle örgütsel vatandaşlık seviyesinin, yaşa bağlı olarak değişkenlik gösterdiği; ortalama değerler bazında da yaş ilerledikçe ÖVD sergileme isteğinin yükseldiği; çalışanların yaş aldıkça ÖVD’yi daha çok gösterdikleri belirtilmiştir (Karacaoğlu ve Güney, 2010: 146).

$\mathrm{Bu}$ çalışmada yapılan anova analizi soncunda, nezaket ve hizmet kalitesinin medeni durum bakımından anlamlı farklılık göstermediği tespit edilmiştir. Karacaoğlu ve Güney'in yaptıkları çalışmada ise örgütsel vatandaşlık düzeyinin, medeni durum kriterine bağlı olarak farklılık gösterdiği tespit edilmiştir (Karacaoğlu ve Güney, 2010: 147).

Bu çalışmada için yapılan anova analizi soncunda, nezaket ve hizmet kalitesinin eğitim durumu değişkeni oranına göre, anlamlı farklılıklar gösterdiği tespit edilmiştir. İlköğretim düzeyinde özel okul çalışanlarının nezaket ve hizmet kalitesi boyutlarında karşılaştırma yapıldığında, diğer eğitim düzeyindeki çalışanlara oranla daha düşük olduğu bulgularına ulaşılmıştır. Ardıç vd.'nin yaptıkları çalışmada ise, çalışana dair eğitim seviyesi, gelir durumu, özgecilik, nazik olma ve hizmet kalitesi ile sosyal seviye gibi değişkenlerin beklentileri etkilediği; belediye hizmetlerinden faydalanan vatandaşların memnuniyet seviyelerini etkileyen unsurların, vatandaşların eğitim düzeyi, cinsiyetleri, yaşı, gelir düzeyi, ikamet süresi, siyasi duruşu, geçmiş deneyimleri ve uzmanlık seviyeleri olduğu belirtilmiştir (Ardıç vd., 2004: 79)

\section{Regresyon Analizi ile İlgili Sonuç ve Öneriler}

$\mathrm{Bu}$ çalışmada için yapılan regresyon analizi soncunda, nezaket boyutunun özel okullarda hizmet kalitesi açısından anlamlı düzeyde etkilediği ve pozitif yönde olumlu etkileri olduğu sonucuna ulaşılmıştır. Buradan hareketle nezaket davranışının örgütlerdeki iş uyumuna olumlu etkileri ve özel okul çalışanlarının sahip olduğu bilgi, beceri, yetenek gibi kişisel özelliklerini de geliştireceği söylenebilir. Basım ve Şeşen'in yaptıkları araştırmada ise örgütsel vatandaşlık davranışları, bireyler arasında dayanışmayı artırarak; verilen hizmetlerin kalitesini, nezaketi ve dayanışmayı artırarak, örgütsel performansın artmasına yol açtığı belirtilmiştir. Bu tarz davranışların, örgütün kültüründe uzun vadeli ve kalıcı gelişim ile motivasyon, uyum ve pozitif yönlü değişim yarattığı ifade edilmiştir (Basım ve Şeşen, 2006: 99). Ayrıca, Özdevecioğlu'nun yaptığı araştırmada; örgütsel vatandaşlık davranışları, örgüt yaşamında çalışanların motivasyonları, işten alacakları tatmin, performansları ve örgüte olan sadakatlerini artırdığı belirtilmiştir (Özdevecioğlu, 2003: 133). Niehoff ve Moorman yaptıkları araştırmada; ÖVD'nin, çalışanların örgüt yapısı dahilinde dayanışma eğilimlerini artırarak, hizmetlerin daha kaliteli sunulmasını sağladığı; nezaketi ve sorumluluk alma isteğini arttırdığı ve 
çalışan performansını artırarak daha özverili ve uyumlu bir çalışan profili yaratılmasını mümkün kıldığı tespit edilmiştir (Niehoff ve Moorman, 1993: 553). Ayrıca, Sezgin yaptığı çalışmada, ÖVD'nin; çalışanların birbirlerine ihtiyaç duymalarına neden olduğunu, örgütsel verimliliğe artırdığını, kaliteli hizmetlerin müşteri memnuniyetini artırdığını ve bireysel gelişime etkisi olduğunu tespit etmiştir (Sezgin, 2005: 317).

\section{SONUÇ}

Yöneticilerin nezaket kuralları içeresinde davranmaları; örgütün verimliliğine, çalışanların memnuniyetine ve tüketicilerin memnuniyetine olumlu katkıları bulunmaktadır. ÖVD çalışanların iş tanımlarının ötesinde, gönüllü olarak sergiledikleri ve örgütün işleyişine olumlu katkı sağlayan rol davranışlarıdır. Çalışanların kendi isteğiyle örgütsel davranışlara katkıda bulunmaları, diğer işçilere yardım etmeleri veya görevinden fazla bir çaba göstermeleri, örgüt başarısında önemli davranışlardır. Bu bağlamda okul yöneticilerinin çalışanlara nezaketle davranmasını, özel okullarda da pozitif etkiler oluşturabilir, üretkenliğe, dayanışmaya, verimliliğe ve hizmet kalitesinin artmasına neden olabilir.

Nezaket, örgüt çalışanının kendi karar ve hareketlerinden etkilenebilecek kişilerle iletişiminde etkileri ortaya çıkmaktadır. Bu konudaki bilinç ve farkındalık, özel okullarda motivasyon ve üretkenliği artırırken, başarıyı da beraberinde getirmektedir. Bu konuda yetersiz kalan özel okul çalışanlarının motivasyon ve üretkenliğinde negatif yönde durumlar gözlenmektedir.

Kişilerarası farklılıklar, genel anlamda sahip oldukları, psikolojik ve kişilik özelliklerinin birbirlerinden farklı olma durumudur. Bu farklılıklar, kişilerin düşünceleri, davranışları, yaşantıları, gelecek planları gibi konularda önemli etkilere sahip olmaktadır. Bu konuların arasında kişiler, örgütsel ortamlarda çalışmaktadır. Örgütsel ortamda birey davranışının gitgide önem kazanması, yöneticilerin bireysel ve kişilerarası farklılıklara odaklanmasına neden olmaktadır. Örneğin; öz disiplini düşük bir çalışanın sergilediği davranışlar, amir ve diğer çalışanlarda belli tutum ve davranışların gelişmesine, bu tutumların diğer çalışanları etkilediğine, fayda ve üretkenliği negatif yönde etkilemesiyle birlikte olumsuz tutum ve davranışların örgüte yansımasına neden olmaktadır.

Kişi-örgüt uyumunda, kişinin tutum ve davranışları, değerleri, amaçları, kişiliği, örgütlerin amaçları, değerleri ve kültürü anlamlı bir bütün ve uyumdur. Bu uyumun gelişmesinde tutum ve davranışların etkileri büyük oranda olmaktadır. Özel okullarda bu boyutların olumlu yönde gelişmesi hem çalışanların hizmet kalitesini artırmakta hem de öğrencilerin eğitim ve öğretim düzeyi istenilen seviyelere çıkmaktadır.

Çalışanların birbirlerine yönelik nezaket dışı zarar verici, haksız davranışlarda bulunması, çalışma barışını tehdit eden ve yöneticilerin çözmek zorunda olduğu önemli problemlerden biridir. Örgütlerde, zaman zaman örgütün işleyişine amaç ve hedeflerine engel teşkil edecek tutum ve davranışlar görülmektedir. Bu davranışlar, örgütün norm ve değerlerine ters düşen davranışlar olmaktadır. Bu tür davranışlar sadece örgütsel amaç ve hedeflere zarar vermekle kalmamakta, aynı zamanda çalışanların günlük yaşamlarını ve iş yaşamlarını olumsuz yönde etkilemektedir. Bu yönde davranışların yoğunlukla yaşandığı ve iyi yönetilemediği iş ortamlarında, psikolojik açıdan kendini mutsuz hisseden birey, örgüte ve işe karşı olumsuz davranışlar sergileyebilecek, dolayısıyla iş performansı negatif yönde etkilenebilmektedir. Bu durumları özel okullara uyarladığımızda da karşımıza aynı sorunlar çıkmaktadır. Dolayısıyla, eğitim seviyelerine bakılmaksızın bu konuda özel okul çalışanlarının hizmet kalitesinin yükselmesine yönelik nezaket davranışının önemini vurgulamalı ve davranışın kazandırılması yönündeki çalışmalar her boyutta önemli olmaktadır. Örgütlerde davranışsal uyum sağlandığında çalışanların işlerinden daha fazla tatmin duydukları, örgütlerine bağlılıklarının artığı ve performanslarının yükseldiği görülmektedir.

\section{7. ÖNERİLER}

Hizmet içi eğitim ve faaliyetlerle çalışanların, fayda ve motivasyonlarının yükseltilmesi gereklidir. Kadınların örgütteki nezaket tutum ve davranışlarının düşük olmasının altında yatan nedensel faktörlerin çok boyutlu ele alınması, kişiliğine ve durumsal koşullarına bağlı olarak davranışın gözlemlenmesi, nedeninin belirlenmesi gereklidir.

Demografik değişkenlere bakılmaksızın örgüt çalışanlarında nezaket ve olumlu iletişim konularının öneminin vurgulanması, çalışanların nezaket davranışını içselleştirip davranış kalıplarının geliştirilmesine yönelik eğitim faaliyetlerinin düzenlenmelidir. 
Özel okul öğretmenlerinin ve diğer çalışan personelin mesleki gelişimleri, çalışanlar ve kurum açısından önemli olduğundan, hizmet içi eğitimlere katılmaları, mesleki yayınları ve alanları gelişmeleri takip etmeleri gereklidir. Yaş oranlarına bakılmaksızın nezaket tutum ve davranışı konusunda bilgilendirici ve bilinçlerini geliştirici eğitim ve seminerler düzenlenmeli ve çok boyutlu olarak ele alınmalıdır.

Okullarda davranışsal yönlü problemlerde yaratıcı çözümlerin üretilmesi konusunda idarecilerin teşvik edici olması, davranışsal problemleri çözme becerilerinde etkili olması, güçlü vizyon geliştirmesi, geleceği öngören ve örgüt iklimine yön veren dönüştürücü idarecilerin yönetmesi, özel okullarda her alanda başarıy beraberinde getirmektedir. Bu nedenle, örgütsel davranış bilincin okullardaki tüm görevlilere kazandırılmalı ve nezaket davranışlarının önemi vurgulanmalıdır.

Rekabetin gün geçtikçe artması ile birlikte kalifiye elemanların kurumlar için birer avantaj unsuru haline gelmesi, insan kaynaklarına verilen önem gün geçtikçe artmaktadır. Kurumlarda sürdürülen faaliyetler sırasında iyileştirilen uygulamalar çalışanlar üzerinde olumlu iş davranışların ortay çıkmasına neden olmaktadır. Geliştirilen olumlu davranışların iş uyumuna ve performansına etkilerinin bilincine varılması, özel okullarda eğitim ve öğretimin; tüm boyutlarda olumlu etkilerinin görülmesine neden olabilecektir.

Nezaket ve örgütsel vatandaşlık bileşenlerinin her boyutta pozitif etkileri göz ardı edilmemeli ve bu konuda özel okullarda farkındalık ve bilinç geliştirilmeli, nezaket dışı tutum ve davranışların tespiti yapılmalı, altında yatan nedenler ortaya çıkartılıp önlemeye yönelik tedbirler alınmalıdır.

Eğitim seviyesi düşük çalışanların nezaket konusunda düşük tutum ve davranışlar sergilediği görülmekle beraber idareciler bu boyuttaki soruna grup eğitimleri vermeli ve davranışı pozitif yönde geliştirmeleri sağlanmalıdır.

Çalışanların neden farklı davranış biçimleri sergiledikleri konusunun tartışılması ve nezaket dışı davranışları önlemeye yönelik eğitici faaliyetler düzenlenmelidir.

Davranışların temel belirleyicilerinden birinin kişilik özellikleri olduğu karşımıza çıkmaktadır. Bu nedenle, nezaket davranışının hizmet kalitesine etkisi karşılaştırıldığında, kişilerarası örgütsel ilişkilerde kişilik özelliklerinin etkilerinin büyük oranda olduğu göz ardı edilmemelidir. Bu konuda tutum ve davranışların geliştirilmesine yönelik eğitici faaliyetler düzenlenmeli, nezaket davranışını örgütte içselleştirmeleri ve çalışanlara kazandırmaları gereklidir.

Nihai olarak, yapılacak araştırmalarda, örneklem büyüklügünün ilin veya ülkenin tamamını kapsayacak şekilde yapılması, okul dışında özel kurumlarda, Sivil Toplum Örgütlerinde ve farklı kurumlarda yapılması bilimsel önerilerin geliştirilmesi açısından yararlı olabilecektir.

\section{KAYNAKLAR}

Altıntaş, F. Ç. (2006). Hizmet Çalışanları Olarak Hemşirelerin Örgütsel Vatandaşlık Davranışı Boyutlarını Belirlemeye Yönelik Bir Analiz, Yönetim Bilimleri Dergisi, 4(2), 81-90.

Ardıç, Kadir vd, (2004). Belediyelerde Hizmet Kalitesinin (Vatandaş Tatmininin) Ölçülmesi (Tokat Belediye'sinde Bir Uygulama), Çă̆daş Yerel Yönetimler Dergisi, 13(3), 63-81.

Arslantaş, C. C. (2008). Yöneticiye Duyulan Güvenin ve Psikolojik Güçlendirmenin Örgütsel Vatandaşlık Davranışı Üzerindeki Etkilerini Belirlemeye Yönelik Görgül Bir Çalışma, TISK Akademi, 3(5), 100-117.

Atkinson, H. and Brown, J. B. (2001). Rethinking Performance Measures: Assessing Progress in UK Hotels, International Journal of Contemporary Hospitality Management, 13(3), 128-135.

Avcı, A. (2015). Örgütsel Vatandaşlık Davranışları: Kavramsal Gelişimi ve Eğitim Örgütleri Açısından Etkileri, Hasan Ali Yücel Eğitim Fakültesi Dergisi, 12(2), 11-26.

Aylin, G. (2018). Aile İşletmelerinde Aile Etkisi ve Örgütsel Ustalık Kavramlarının İşletmeme Performansı Üzerindeki Etkilerinin İncelenmesi, 1. Baskı, İstanbul: Eğitim İletişim Yayınları.

Basım, H. N. ve Şeşen, H. (2006). Örgütsel Vatandaşlık Davranışı Ölçeği Uyarlama ve Karşılaştırma Çalışması, Ankara Üniversitesi Siyasal Bilgiler Fakültesi Dergisi, 61(4), 83-102. 
Bayar, M. (2020). Yalın Yönetim Anlayışının, Çalışanların Görev Performansına Etkilerine Yönelik Bir Araştırma. İşletme Araştırmaları Dergisi, 12(2), 1984-2001.

Bayram, L. (2006). Geleneksel Performans Değerlendirme Yöntemlerine Yeni Bir Alternatif: 360 Derece Performans Değerlendirme, Sayıştay Dergisi, 62(1), 47-65.

Baytok, A. ve Ergen, F. D. (2013). Hizmetkâr Liderliğin Örgütsel Vatandaşlık Davranışına Etkisi: İstanbul ve Afyonkarahisar'daki Beş Yıldızlı Otel İşletmelerinde Bir Araştırma, İşletme Araştırmaları Dergisi, 5(4), 105-132.

Bingöl, D. (2016). İnsan kaynakları Yönetimi, 10. Baskı, İstanbul: Beta Yayınları.

Brignall, S. and Ballantıne, J. (1996). Performance Measurement in Service Businesses Revisited, International Journal of Service Industry Management, 7(1), 6-31.

Clarke, R. Daly, L. Robinson, K. Naughten, E. Cahalane, S. Fowler, B. and Graham, I. (1991). Hyperhomocysteinemia: an Independent Risk Factor For Vascular Disease, New England Journal of Medicine, 324(17), 1149-1155.

Çavus, M. F. ve Develi, A. (2015). İnsan Kaynakları Yönetimi Uygulamalarının Örgütsel Vatandaşlık Davranışı Üzerindeki Etkileri, TISK Akademi, 10(20), 230-249.

Çetin, M. Ö. (2004). Örgütsel Vatandaşlık Davranışı, Ankara: Nobel Yayın Dağıtım.

Demir, A. S. ve Taşkın, H. (2008). İşletme Performansı Ölçme Modellerinin Karşılaştırılması: Kuantum Performansı, Maddi Olmayan Varlıkların İzlenmesi, Performans Prizması ve Skandia Kılavuzu Modelleri, Journal of Yaşar University, 3(11), 1695-1709.

Demireli, C. ve Bayraktar, U. (2014). Hizmet Kalitesi ve Hizmet Değerinin Müşteri Memnuniyetine Etkisi: Demiryolu Taşımacılığında Bir Uygulama, Gaziantep University Journal of Social Sciences, 13(4), 919-937.

Demirtaş, Z. (2010). Teachers' Job Satisfaction Levels. Procedia-Social and Behavioral Sciences, Published by Open access under 9, 1069-1073, Elsevier Ltd.

Edward, D. B. (2000). Rekabet Üstü, Çeviren: Akın Arslan, Oya Özel, 2. Baskı, İstanbul: Remzi Kitapevi.

Erdoğan, S. ve Yazıcıŏlu, Y. (2004). SPSS Uygulamalı Bilimsel Araştırma Yöntemleri, Ankara: Beta Yayınları.

Fitzgerald, S.L. and Johnston, R. Brignall, S. (1991). Performance Measurement in Service Businesses, London: CIMA. The DurAble CorporATion, 264.

Göksoy, S., Emen, E ve Yenipınar, Ş. (2014). Öğretmenlerin Öz Liderlik Rolleri İle Örgütsel Vatandaşlık Davranışları Arasındaki İlişkinin İncelenmesi, KSÜ Sosyal Bilimler Dergisi, 11(1), 103-116.

Gündüz, Y., Lüdecke, T. and Uhrig-Homburg, M. (2007). Trading Credit Default Swaps Via İnterdealer Brokers, Journal of Financial Services Research, 32(3), 141-159.

Gürbüz, S. (2008). İş Tatmini ve Adalet Algısının Örgütsel Vatandaşlık Davranışına Etkisi, Amme İdaresi Dergisi, 41(4), 49-77.

Hasan, G. (2005). Dış Kaynak Kullanma Nedenleri ve Taşıdığı Riskler: İmalat Sanayiinde Bir Uygulama, Yönetim ve Ekonomi Araştırmaları Dergisi, 3(4), 157-184.

Hunton, J. E. Lipincott, B. ve Reck, J. L. (2003). Enterprise Resource Planning Systems: Comparing Firm Performance of Adopters and Nonadopters, International Journal of Accounting Information Systems, 4(3), 165-184.

İpek, C. (2012). Öğretmen Algılarına Göre Ortaöğretim Kurumlarında Örgütsel Kültür ve Örgütsel Vatandaşlık Davranışı, Kuram ve Uygulamada Ĕ̆itim Yönetimi Dergisi, 18(3), 399-434.

Kaplan, R. S. ve Norton, D. P. (1999). Balanced Scorecard, Çeviren: Serra Egeli, İstanbul: Sistem Yayıncllı.

Kara, N. O. Yeşilaydın, G. ve Hancığlu, Y. (2018). Türkiye'de Rekabet Alanında Yapılan Lisansüstü Tezlere Yönelik Bir İnceleme, Süleyman Demirel Üniversitesi Vizyoner Dergisi, 9(20), 149-165. 
Karacaoğlu, K. ve Güney, Y. (2010). Öğretmenlerin Örgütsel Bağl1lıklarının, Örgütsel Vatandaşlık Davranışları Üzerindeki Etkisi: Nevşehir İli Örneği, Öneri Dergisi, 9(34), 137-153.

Karalar, R. (2008). Genel İşletme, Eskişehir: Açık Öğretim Fakültesi Yayınları.

Karaman, A. ve Aylan, S. (2012). Örgütsel Vatandaşlık, Kahramanmaraş Sütçü İmam Üniversitesi İktisadi ve İdari Bilimler Fakültesi Dergisi, 2(1), 35-48.

Karaman, R. (2013). İşletmelerde Performans Ölçümünün Önemi ve Modern Bir Performans Ölçme Aracı Olarak Balanced Scorecard, Celal Bayar Üniversitesi Dergisi, 8(16), 411-427.

Kaya, Ş. D. (2013). Örgütsel Vatandaşlık Davranışı, Türk İdare Dergisi, 0(476), 265-287.

K1lıç, B. ve Eleren, A. (2009). Turizm Sektöründe Hizmet Kalitesi Ölçümü Üzerine Bir Literatür Araştırması, Alanya İşletme Fakültesi Dergisi, 1(1), 91-118.

Koçel, T. (2003). İşletme Yöneticiliği, 9. Baskı, İstanbul: Beta Yayınları.

Köse, S., Kartal, B. ve Kayalı N. (2003). Örgütsel Vatandaşlık Davranışı ve Tutuma İlişkin Faktörlerle ilişkisi Üzerine Bir Araştırma, Erciyes Üniversitesi İktisadi ve İdari Bilimler Fakültesi Dergisi, 0(20), 1-19.

Mehtap, Ö. (2011). Örgüt İçi Politik Davranışların Örgütsel Vatandaşlık Davranışı Üzerindeki Etkisi, İstanbul Üniversitesi. Sosyal Bilimler Enstitüsü, Yayımlanmamış Doktora Tezi, İstanbul.

Nergiz, H. G. (2016). Turizm Sektöründe Örgütsel Vatandaşlık Davranışı Üzerine Bir Değerlendirme, Yönetim Bilimleri Dergisi, 14(27), 217-247.

Niehoff, B. P. and Moorman, R. H. (1993). Justice as a Mediator of the Relationship Between Methods of Monitoring and Organizational Citizenship Behavior, Academy of Management Journal, 36(3), 527-556.

Organ, D. W. (1988). Organizational Citizenship Behavior: The Good Soldier Syndrome, Lexington: Books/DC Heath and Com.

Özcan, E.D., Vardarlıer, P., Karabay, M.E., Konakay, G. ve Çetin, C. (2012). Liderliğin Örgütsel Vatandaşlık Davranışı ve İşten Ayrılma Niyeti Üzerindeki Etkisinde Güvenin Rolü, Öneri Dergisi, 10(37), 1-13.

Özdevecioğlu, M. (2003). Örgütsel Vatandaşlık Davranışı İle Üniversite Öğrencilerinin Bazı Demografik Özellikleri ve Akademik Başarıları Arasındaki İlişkilerin Belirlenmesine Yönelik Bir Araştırma, Erciyes Üniversitesi Iktisadi ve İdari Bilimler Fakültesi Dergisi, 0(20), 117-135.

Özdevecioğlu, M. (2009). Örgütlerarası Vatandaşlık Davranışları: Teorik Çerçeve ve Bir Ölçek Geliştirme Çalışması, Erciyes Üniversitesi İktisadi ve İdari Bilimler Fakültesi Dergisi, 0(33), 47-67.

Parker, C. (2000). Performance Measurement, Work Study, 49(2), 63-66.

Paşamehmetoğlu, A. ve Poyraz, A. B. (2013). Örgütsel Kimlik Algısı, Örgütsel Bağlllık ve Örgütsel Vatandaşlık Davranışı Arasındaki İlişkinin Belirlenmesine Yönelik Bir Araştırma, Journal of Business Economics, 2(4), 75-89.

Podsakoff, P. M. Mackenzıe, S. B. Paine, J. B. and Bachrach, D. G. (2000). Organizational Citizenship Behaviors: A Critical Review of the Theoritical and Empirical Literature and Suggestions for Future Research, Journal of Management, 26(3), 513-563.

Polatcı, S. ve Cindiloğlu, M. (2013). Kişi-Örgüt Uyumunun Örgütsel Vatandaşlık Davranışına Etkisi: Duygusal Bağlılığın Aracılık Rolü, Suleyman Demirel University Journal of Faculty of Economics E Administrative Sciences, 18(3), 299-318.

Pollert, A. (1988). The 'Flexible Firm': Fixation or Fact?, Work, Employment and Society, 2(3), 281-316.

Sezgin, F. (2005). Örgütsel Vatandaşlık Davranışları: Kavramsal Bir Çözümleme ve Okul Açısından Bazı Çıkarımlar, Gazi Üniversitesi Gazi Ĕ̆itim Fakültesi Dergisi, 25(1), 317-339.

Sökmen, A. (2011). Örgütsel Vatandaşlık Davranışı Cinsiyete Göre Farklılık Gösterir Mi? Otel İşletmeleri Açısından Bir Değerlendirme, Gaziantep University Journal of Social Sciences, 10(1), 147-163. 
Şahin, Ü. (1999). Hastane işletmeciliğinde Kalite (Editör: Nurullah Uçkun), Eskişehir: Hastane Yönetimi, Kalite, TKY, ISO.

Tek, Ö. B. (1999). Pazarlama İlkeleri Türkiye Uygulamaları Global Yönetimsel Yaklaşım, İstanbul: Beta Basım Yayın.

Türkay, O. (2015). Çalışma Yaşamı Kalitesinin İş Memnuniyeti ve Bağlılık Üzerine Etkileri: Seyahat Acentaları Üzerine Bir Araştırma, Yönetim ve Ekonomi: Celal Bayar Üniversitesi İktisadi ve İdari Bilimler Fakültesi Dergisi, 22(1), 239-256.

Uysal, Ş. (2015). Performans Yönetimi Sisteminin Tanımı, Tarihçesi, Amaç ve Temel Unsurlarına Genel Bir Bakış, Electronic Journal of Vocational Colleges, 5(2), 32-39.

Van Dyne, L., Graham, J. W. and Dienesch, R. M. (1994). Organizational Citizenship Behavior: Construct Redefinition, Measurement and Validation, Academy of Management Journal, 37(4), 765-802.

Williams, L. J. and Anderson, S. E. (1991). Job Satisfaction and Organizational Commitment as Predictors of Organizational Citizenship and in-Role Behaviors, Journal of Managment, 17(3), 601-617.

Yasım, Y. K. ve Işık, U. (2017). Yapısal Güçlendirmenin Örgütsel Vatandaşlık Davranışı Üzerine Etkisi: Taş İşleme Sektörü Çalışanları Üzerinde Bir Uygulama, Sosyal Bilimler Araştırmaları Dergisi, 7(2), 377-386.

Yeşiltaş, M. Türkmen, F. ve Ayaz, N. (2011). Otel İşletmelerinde Algılanan Örgütsel Prestijin Örgütsel Vatandaşlık Davranışları Üzerindeki Etkileri, C.Ü. İktisadi ve İdari Bilimler Dergisi, 12(2), 171-189.

Yıldız, S. (2011). İşletme Performansının Ölçümü Üzerine Bankacıllk Sektöründe Bir Araştırma, Erciyes Üniversitesi İktisadi ve İdari Bilimler Fakültesi Dergisi, 0(36), 179-193.

Yılmaz, R. (2018). Psikolojik İklimin Örgütsel Vatandaşlık Davranışı Üzerindeki Etkisinde İçsel Motivasyonun Aracılık Rolü: Sanayi İşletmelerinde Bir Araştırma. Selçuk Üniversitesi, Sosyal Bilimler Enstitüsü, Yayımlanmamış Doktora Tezi, Konya. 